\title{
The genus Schizopera (Copepoda, Harpacticoida) in the Pilbara region of Western Australia, with description of a new species and its molecular and morphological affinities
}

\author{
T. Karanovic ${ }^{1}$ and J. McRae ${ }^{2}$ \\ ${ }^{1}$ Hanyang University, Department of Life Sciences, Seoul 133-791, Korea and University of Tasmania, \\ Institute for Marine and Antarctic Studies, Hobart, Tasmania 7001, Australia. \\ Email: Tomislav.Karanovic@utas.edu.au \\ 2 Bennelongia Environmental Consultants, 5 Bishop Street, Jolimont, WA 6014, Australia. \\ Email: jane.mcrae@bennelongia.com.au
}

\begin{abstract}
The predominantly marine genus Schizopera Sars, 1905 has only two significant inland water species flocks, one in the ancient African Lake Tanganyika and the other in subterranean waters of Western Australia. Despite a great potential for studies of freshwater invasions, very little research has been done on these copepods, especially in the Pilbara region. We describe here S. cooperi sp. nov. from a bore hole about $45 \mathrm{~km}$ NW of Paraburdoo, which sheds new light on the previous sparse records of this genus in the region. Morphological characters suggest a close relationship between the new species and S. weelumurra Karanovic, 2006, a species described on the basis of a single female from a locality that lies some $100 \mathrm{~km} \mathrm{NE}$, with only minor differences in the proportion of some setae and spines. Phylogenetic analyses of the mtCOI partial sequences suggest that the new species has no close relatives among Western Australian congeners, molecular data for the presumably closely related S. weelumurra are missing. Molecular data suggest a closer relationship between $S$. cooperi and three congeners from the Yilgarn region than between it and another (as yet unidentified) congener from the Pilbara, suggesting multiple colonisation events in both regions. An overview of the genus in the Pilbara highlights the need for more extensive sampling and for the use of molecular data to resolve issues of disjunct distribution patterns and delineation of morphologically similar species.
\end{abstract}

KEYWORDS: barcoding, phylogeny, stygofauna, taxonomy

\section{INTRODUCTION}

The genus Schizopera was established by Sars (1905), with S. longicauda Sars, 1905 as the type species. Today, there are about 96 valid species and subspecies worldwide (Karanovic and Cooper 2012; Walter and Boxshall 2013). They are distributed in a variety of marine, brackish and freshwater habitats around the world, which makes them an ideal group for testing hypotheses of multiple invasions of freshwater (Karanovic and Cooper 2012), which was suggested for copepods generally (Boxshall and Jaume 2000, Karanovic 2008). The genus is, however, predominantly marine, with only two significant inland water species flocks, one in the ancient African Lake Tanganyika (Sars 1909; Gurney 1928; Lang 1948; Rouch and Chappuis 1960) and the other in subterranean waters of Western Australia (Karanovic 2004, 2006; Karanovic and Cooper 2012). Unfortunately, a great number of species descriptions are incomplete and/or inadequate. Because of that, and because of the normal expansion of generic boundaries resulting from the inclusion of new species, systematics of the genus Schizopera have been very difficult. Lang $(1948,1965)$ maintained clarity in the generic diagnosis by suggesting the presence of a "transformed spine" on the male third leg exopod is a synapomorphy but this structure is, in fact, an enormously enlarged tubular pore (Karanovic and Cooper 2012). Attempts to split the genus based on the segmentation of endopods of first and fourth swimming legs (Apostolov 1982; Wells and Rao 1976; Bodin 1997; Boxshall and Halsey 2004) were subsequently questioned both based on morphological (Mielke 1992, 1995; Karanovic 2004; Wells 2007; Huys 2009) and molecular evidence (Karanovic and Cooper 2012), and are now abandoned. The only exception is the genus Eoschizopera Wells and Rao, 1976, which was originally designed to accommodate all doubtful members of the genus Schizopera, but was later redefined to include only four species by Karanovic (2004). Its validity has been supported by a set of morphological synapomorphies but 
its subgeneric division proposed by Apostolov (1982) has also been abandoned (Boxshall and Halsey 2004; Wells 2007; Huys 2009).

In Australia the first record of the genus Schizopera was that of $S$. clandestina (Klie, 1924) by Storey et al. (1993), who listed it without any drawings or descriptions from surface waters of Gardner Lake during its freshwater phase (the lake becomes brackish in summer), less than one $\mathrm{km}$ from the southern coast of Western Australia. Halse et al. (2002) reported the same species from Lake Coyrecup, a small semipermanent saline lake in south-western Western Australia, some $125 \mathrm{~km}$ from the nearest coast. This species was originally described by Klie (1923) from German brackish waters of various salinities, and later reported from many other parts of the world (Lang 1948; Bodin 1997). An incredible range of morphological variability and several described subspecies (Wells 2007) led Karanovic and Cooper (2012) to suggest that $S$. clandestina could be a species-complex, and that the Australian populations are unlikely to belong to a species described from German brackish waters. This matter would need a proper taxonomic revision, with redescription of the type material, as the original description is no longer adequate for modern taxonomic standards in this group. Karanovic (2004) described five allopatric subterranean species from various parts of the vast Yilgarn region of Western Australia: S. austindownsi Karanovic, 2004; S. depotspringsi Karanovic, 2004; S. jundeei Karanovic, 2004; S. oldcuei Karanovic, 2004; and S. uramurdahi Karanovic, 2004. Two years later, Karanovic (2006) described another two allopatric subterranean species from the Pilbara region of Western Australia: S. roberiverensis Karanovic, 2006 and S. weelumurra Karanovic, 2006. The latter was described from a single female from a bore hole approximately $65 \mathrm{~km}$ north of Tom Price (Figure 1), while the former was found in four different bore holes in close proximity some $48 \mathrm{~km}$ west of Pannawonica (the type locality), but was also reported from another bore (PANNASLK4) about $10 \mathrm{~km}$ east of the type locality, as well as from a locality near Paraburdoo (bore TPB2-1) almost $250 \mathrm{~km}$ farther south-east (Figure 1). The very disjunct localities of $S$. roberiverensis belong to more or less interconnected waterways, but are 35 , 45, and $295 \mathrm{~km}$ from the nearest sea shore respectively, with no Schizopera records in between. Experience from other studies on subterranean copepods with similarly wide distribution show them usually to be complexes of cryptic species (Karanovic and Krajicek 2012; Karanovic and Cooper 2012), and morphological hypotheses about the specific status of different populations of $S$. roberiverensis should be tested with molecular tools.

Apparently, the genus Schizopera is much rarer in the Pilbara region than in the Yilgarn, which Karanovic (2006) explained by lower salinities in the former. This was demonstrated by Karanovic and Cooper (2012), who described seven species and one subspecies with significant size differentiation and frequent sympatry from Yeelirrie calcretes in a very small area in the northern Yilgarn: S. akation Karanovic and Cooper, 2012; S. akolos Karanovic and Cooper, 2012; S. analspinulosa s. str. Karanovic and Cooper, 2012; S. analspinulosa linel Karanovic and Cooper, 2012; S. emphysema Karanovic and Cooper, 2012; S. kronosi Karanovic and Cooper, 2012; S. leptafurca Karanovic and Cooper, 2012; and S. uranusi Karanovic and Cooper, 2012. Using a combined morphological and molecular approach they were able to demonstrate that both explosive radiation and multiple colonisations are responsible for this unprecedented diversity, that sister species have parapatric distributions and show niche partitioning in the area of overlap, and that there is no evidence for parallel evolution, interspecific size differentiation being a result of different phylogeny (the latter also demonstrated for some subterranean cyclopoid copepods in the Pilbara region by Karanovic and Krajicek (2012)). Another 10 or so new species of Schizopera have been discovered in calcretes around Lake Way and Lake Maitland (T. Karanovic, unpublished data) that are awaiting formal description. It seems at this stage that detailed sampling of other areas in the Yilgarn, combined with the use of molecular tools, will result in discoveries of many more new species of Schizopera in Australia, in addition to about 25 species we are already aware of.

Here we describe a new species from the Pilbara, which is the third member of this genus from this region. Material of this species was previously used (as one of the outgroups) in the molecular study of Karanovic and Cooper (2012), where this species was provisionally identified as "S. sp. I". Its locality lies between the two disjunct localities of the abovementioned problematic $S$. roberiverensis (Figure 1), but we show below that its affinities lie much more closely to the other congener from this region. Another aim of this study was to test phylogenetic relationships, based on molecular data, between our new species and another (as yet unidentified) species from the Pilbara ( $S . s p$. 2; see Figure 1), and between these two species and congeners from the Yilgarn. Although the Pilbara and Yilgarn are neighbouring regions, they show remarkable differences in most major groups of stygofauna that have been well studied. For example, diving beetles are completely absent from the Pilbara region (Watts and Humphreys 2006; Leys and Watts 2008), ostracods show differences at the tribus level (Karanovic 2007), and copepods are mostly different at the genus level (Karanovic 2006; Karanovic 2010; Karanovic et al. 2011), with no shared stygobitic species (Humphreys 2008). Exploring the phylogenies of Schizopera, so far the only shared genus among stygobitic copepods in the two regions, has potentially wider scientific interest.

Employing molecular techniques in addition to traditional morphology is one of the most important recent developments in animal taxonomy and systematics. Recently, DNA-based species identification 
methods, referred to as "DNA barcoding", have been widely employed to estimate levels of species diversity, with the 5'end of the mitochondrial cytochrome C oxidase subunit 1 gene (COI) proposed as the "barcode" for all animal species (Hebert et al. 2003). The advantage of COI is that it often shows low levels of genetic variation within species, but high levels of divergence between species (usually $>15 \%$ among crustacean species, Lefébure et al. 2006). The availability of so-called "universal" primers developed by Folmer et al. (1994) for the PCR-amplification of COI also greatly facilitates the use of this marker to investigate species boundaries in animals, and these primers have previously been employed successfully to PCR-amplify copepod DNA (Adamowicz et al. 2007; Bradford et al. 2010; Sakaguchi and Ueda 2010; Karanovic and Cooper 2011a, b, 2012).

With the inclusion of our new species, the genus Shizopera now numbers 16 described congeners from Australia, and we provide a key for their identification at the end of this paper based on female morphological characters.

\section{MATERIAL AND METHODS}

Specimens of the new species were collected on a single occasion with a hand net from a groundwater bore in Hardy Deposit, about $45 \mathrm{~km} \mathrm{NW}$ of Paraburdoo. The population consisted of nine males, nine females and six copepodids. Two females were destroyed for molecular analysis, and all other specimens are deposited in the Western Australian Museum (WAM) in Perth. Collection numbers and other details are provided in the "Material examined" section below. Another species from the Pilbara region was collected with a hand net from a bore some $60 \mathrm{~km}$ north of Tom Price and only $5 \mathrm{~km}$ away from the type locality of $S$. weelumurra. It was provisionally identified as $S$. $s p$. 2, because only one male and one juvenile specimen were collected (female characters are much more important in this genus, and males are still unknown for three Australian congeners, including $S$. weelumurra). Preliminary examination of the male suggested that this species may be closer to $S$. roberiverensis than to $S$. weelumura, but this will have to be checked on newly collected material as both specimens were destroyed for molecular analysis (Table 1). Specimens of the six Schizopera species from Yeelirrie used in our molecular analysis, as well as those of the two outgroup taxa from the family Canthocamptidae Sars, 1906 (Australocamptus hamondi Karanovic, 2004 and Elaphoidella humphresi Karanovic, 2006), were collected with a combination of various pumping techniques and hand nets, details of which can be found in Karanovic and Cooper (2012).

All samples were preserved in the field in cold $100 \%$ ethanol, kept on ice or in a refrigerator, and sorted in a laboratory. Each sample was given a unique four digit lab code, and these were used throughout the

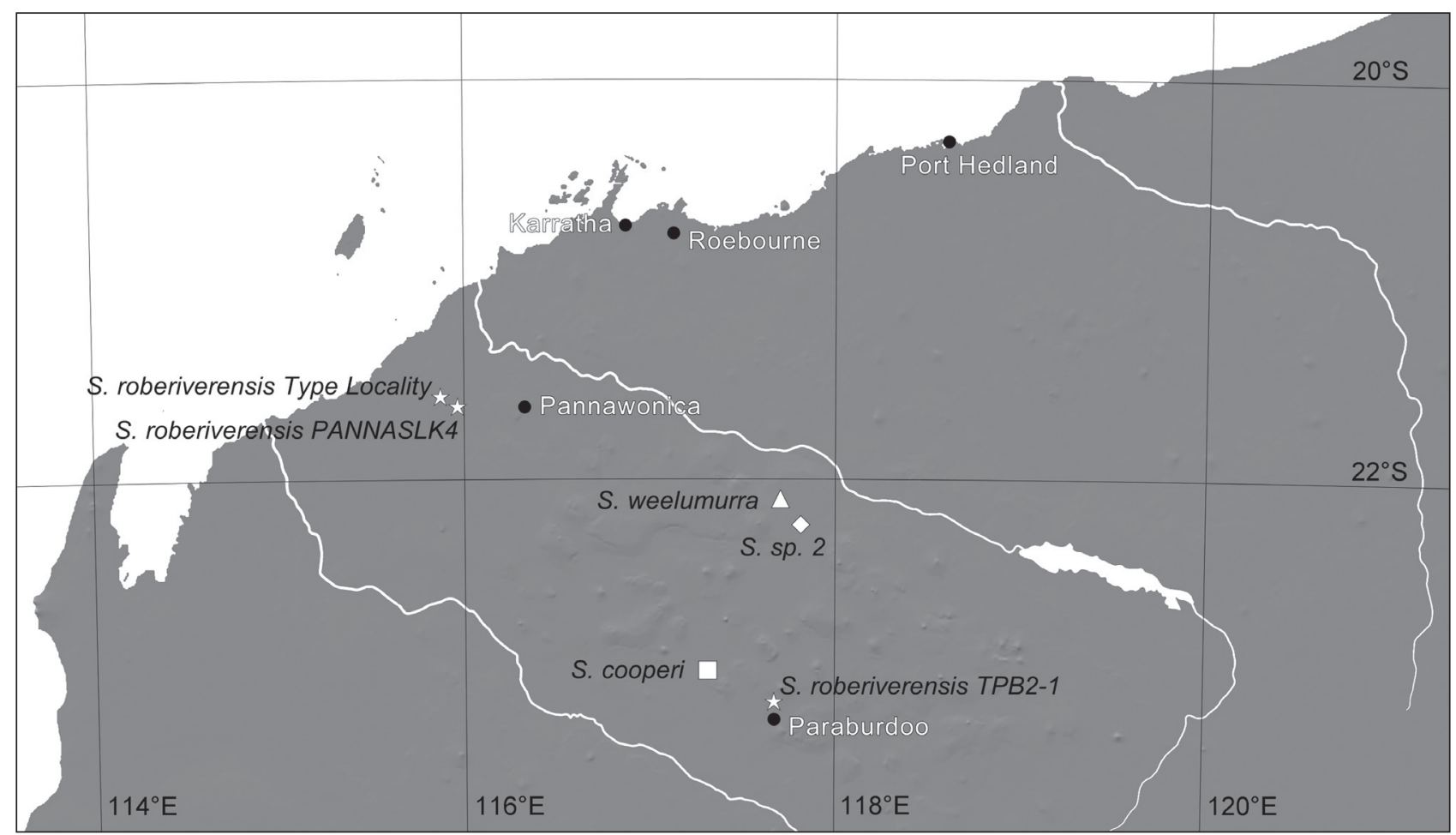

FIGURE 1 Map of the Western Australian Pilbara region showing localities of the Schizopera species. 
TABLE 1 List of copepod specimens for which the COI fragment was successfully amplified.

\begin{tabular}{|c|c|c|c|c|c|}
\hline Code & Species & Region & Bore Number & Date & GenBank \\
\hline $505 / 6$ & S. cooperi sp. nov. & Pilbara & HAMB003 & 18 Sep 2010 & JQ390555 \\
\hline $7081 \mathrm{a}$ & A. hamondi & Yilgarn & 312 & 13 Jan 2010 & JN039160 \\
\hline $7081 b$ & A. hamondi & Yilgarn & 312 & 13 Jan 2010 & JN039163 \\
\hline 7106 & S. sp. 2 & Pilbara & FMGSM1585 & 27 Feb 2010 & JQ390556 \\
\hline 7122 & A. hamondi & Yilgarn & 312 & 19 Mar 2010 & JN039165 \\
\hline 7131 & S. leptafurca & Yilgarn & YYHC085B & 18 Mar 2010 & JQ390557 \\
\hline 7304 & S. emphysema & Yilgarn & YYAC1004C & 27 Aug 2009 & JQ390558 \\
\hline 7308 & S. kronosi & Yilgarn & YYAC1007A & 27 Aug 2009 & JQ390559 \\
\hline 7342 & S. akation & Yilgarn & YYAC284 & 12 Nov 2009 & JQ390560 \\
\hline 7342.1 & S. uranusi & Yilgarn & YYAC284 & 12 Nov 2009 & JQ390561 \\
\hline 7342.2 & S. uranusi & Yilgarn & YYAC284 & 12 Nov 2009 & JQ390562 \\
\hline 7360 & S. analspinulosa linel & Yilgarn & LUNK1 & 12 Jan 2010 & JQ390563 \\
\hline 7374 & S. uranusi & Yilgarn & YYAC1007 & 12 Nov 2009 & JQ390564 \\
\hline 7389 & S. leptafurca & Yilgarn & YYAC118 & 12 Nov 2009 & JQ390565 \\
\hline 7417 & S. leptafurca & Yilgarn & YYAC35 & 12 Nov 2009 & JQ390566 \\
\hline 7417 & S. kronosi & Yilgarn & YYAC35 & 12 Nov 2009 & JQ390567 \\
\hline 7421.1 & S. leptafurca & Yilgarn & YYAC33 & 12 Nov 2009 & JQ390568 \\
\hline 7421.2 & S. leptafurca & Yilgarn & YYAC33 & 12 Nov 2009 & JQ390569 \\
\hline 7433 & S. leptafurca & Yilgarn & YYAC328 & 12 Nov 2009 & JQ390570 \\
\hline 7439 & S. uranusi sp. 2 & Yilgarn & YYAC248 & 12 Nov 2009 & JQ390571 \\
\hline 7730 & S. sp. 2 & Pilbara & FMGSM1585 & 20 Jan 2010 & JQ390572 \\
\hline 7991 & E. humphreysi & Pilbara & FMGSM1529 & 23 Jan 2010 & JN039161 \\
\hline 8110 & E. humphreysi & Pilbara & FMGSM3644 & 2 Mar 2010 & JN039166 \\
\hline 8119 & E. humphreysi & Pilbara & FMGSM3645 & 1 Mar 2010 & JN039173 \\
\hline 8302 & S. uranusi & Yilgarn & YYAC0019B & 20 Mar 2010 & JQ390573 \\
\hline 8385 & S. leptafurca & Yilgarn & YYAC0014D & 17 Mar 2010 & JQ390574 \\
\hline 8393 & S. leptafurca & Yilgarn & YYAC328 & 17 Mar 2010 & JQ390575 \\
\hline 8393 & S. kronosi & Yilgarn & YYAC328 & 17 Mar 2010 & JQ390576 \\
\hline 8417 & S. uranusi & Yilgarn & YYAC0016A & 20 Mar 2010 & JQ390577 \\
\hline 8417 & S. leptafurca & Yilgarn & YYAC0016A & 20 Mar 2010 & JQ390578 \\
\hline 8427 & S. uranusi & Yilgarn & YYHC0139 & 17 Mar 2010 & JQ390579 \\
\hline 8464 & S. leptafurca & Yilgarn & YYHC0049K & 20 Mar 2010 & JQ390580 \\
\hline 8479 & S. uranusi & Yilgarn & YYD26 & 15 Mar 2010 & JQ390581 \\
\hline 8479 & S. leptafurca & Yilgarn & YYD26 & 15 Mar 2010 & JQ390582 \\
\hline 8479 & S. akation & Yilgarn & YYD26 & 15 Mar 2010 & JQ390583 \\
\hline 8496 & S. akolos & Yilgarn & YYD22 & 15 Mar 2010 & JQ390584 \\
\hline 8496 & S. akation & Yilgarn & YYD22 & 15 Mar 2010 & JQ390585 \\
\hline 8517 & S. analspinulosa s. str. & Yilgarn & SB14-1 & 16 Mar 2010 & JQ390586 \\
\hline 8517 & S. akation & Yilgarn & SB14-1 & 16 Mar 2010 & JQ390587 \\
\hline 8527 & A. hamondi & Yilgarn & 312 & 16 Mar 2010 & JN039170 \\
\hline 8533 & S. analspinulosa linel & Yilgarn & LUNK1 & $16 \operatorname{Mar} 2010$ & JQ390588 \\
\hline 8533 & S. akation & Yilgarn & LUNK1 & 16 Mar 2010 & JQ390589 \\
\hline 8538 & S. leptafurca & Yilgarn & YYAC118 & 21 Mar 2010 & JQ390590 \\
\hline
\end{tabular}


investigation, and are also used for our COI sequences from different localities and/or sampling occasions (Table 1). Bores established for hydrogeological work, mineral exploration and water monitoring have prefixes or suffixes of relevance only to that drilling program. These codes are used for each species to aid specification of the location (Table 1), and precise coordinates were provided in Karanovic and Cooper (2012).

Specimens for morphological observation were dissected and mounted on microscope slides in Faure's medium, which was prepared following the procedure discussed by Stock and von Vaupel Klein (1996), and dissected appendages were then covered by a coverslip. Before that, the entire animal and subsequently its urosome were examined and drawn in propylene glycol $(\mathrm{CH} 3 \mathrm{CH}(\mathrm{OH}) \mathrm{CH} 2 \mathrm{OH})$, while mounted between two human hairs under a coverslip, so that the animal and urosome would not be compressed. By manipulating the coverslip carefully by hand, the whole animal or a particular appendage could be positioned in different aspects, making possible the observation of morphological details. During the examination of appendages dissected in Faure's medium water slowly evaporated and appendages eventually remained in a completely dry medium, ready for long term depositing without need for additional sealing. All line drawings were prepared using a drawing tube attached to a Leica MB2500 phase-interference compound microscope, equipped with N-PLAN $(5 x, 10 x, 20 x, 40 x$ and $63 x$ dry) or PL FLUOTAR (100x oil) objectives. Specimens that were not drawn were examined in propylene glycol and, after examination, were again preserved in $100 \%$ ethanol. Specimens for scanning electron microscopy were transferred from pure ethanol into pure isoamylacetate for two hours, critical-point dried, coated in gold and observed under a Hitachi S-4700 microscope on the in-lens detector, with an accelerating voltage of 10 $\mathrm{kV}$ and working distances between 12.3 and $13.4 \mathrm{~mm}$; micrographs were taken with a digital camera. Digital photographs were processed and combined into plates using Adobe Photoshop CS4. The map was created using software MapCreator 2.0.

Morphological terminology follows Huys and Boxshall (1991), except for caudal ramus setae numbering (not used) and small differences in the spelling of some appendages (antennula, mandibula, maxillula instead of antennule, mandible, maxillule), in an attempt to standardise the terminology for homologous appendages in different crustacean groups. Sensilla and pores on all somites (body segments) were numbered consecutively from the anterior to posterior part of the body, and from the dorsal to ventral side, to aid in the recognition of serially homologous structures and future comparisons with other species; they are not intended as a novel terminology. Biospeleological terminology follows Humphreys (2000).

Specimens for molecular analysis were examined without dissection under a compound microscope (objective $63 \mathrm{x}$ dry) in propylene glycol, using a cavity well slide with a central depression. After examination they were returned to $100 \%$ ethanol. DNA was extracted using the GENTRA method (Puregene) according to the manufacturer's protocol for fresh tissues. PCR amplifications of a 623-bp fragment from the mitochondrial COI gene were generally carried out with the "universal" primers LCOI490 and HCO2198 (Folmer et al. 1994), as well as with additional 'nested' primers designed by Ms Kathleen Saint (South Australian Museum) from preliminary copepod COI sequence data and used in combination with universal primers to improve the PCR-amplification efficiency (for details see Karanovic and Cooper 2012). PCR-amplifications were carried out in $25 \mu \mathrm{L}$ volumes containing $4 \mathrm{mM} \mathrm{MgCl} 2$, $0.20 \mathrm{~mm}$ dNTPs, $1 \times$ PCR buffer (Applied Biosystems), 6 pmol of each primer and $0.5 \mathrm{U}$ of AmpliTaq Gold (Applied Biosystems). PCR amplification was performed under the following conditions: $94{ }^{\circ} \mathrm{C} 9 \mathrm{~min}$, then 34 cycles of $94{ }^{\circ} \mathrm{C} 45 \mathrm{~s}$; annealing $48{ }^{\circ} \mathrm{C} 45 \mathrm{~s} ; 72{ }^{\circ} \mathrm{C}, 60$ $\mathrm{s}$; with a final elongation step at $72{ }^{\circ} \mathrm{C}$ for $6 \mathrm{~min}$. PCR products were purified using a vacuum plate method and sequencing was undertaken using the ABI prism Big Dye Terminator Cycle sequencing kit (PE Applied Biosystems, Foster City, CA). Sequencing was carried out on an ABI 3700 DNA analyser and sequences were edited and manually aligned in SeqEd version 1.0.3 (Applied Biosystems). DNA was extracted and the COI fragment successfully PCR-amplified from 43 copepod specimens (Table 1).

Phylogenetic analyses of the COI sequence data were conducted using a Bayesian Inference (BI) approach with MRBAYES v.3.2 (Huelsenbeck and Ronquist 2001; Ronquist and Huelsenbeck 2003). The program MODELTEST (version 3.7; Posada and Crandall 1998) with the Akaike Information Criterion was used to show that a General Time Reversible (GTR) model (Rodríguez et al. 1990), with a proportion of invariant sites (I) and unequal rates among sites (G) (Yang 1996) was most appropriate for BI analyses. The analyses were carried out using default uninformative priors with four chains run simultaneously for five million generations in two independent runs, sampling trees every 500 generations. After this number of generations the final standard deviation of split frequencies had reduced to 0.0045 and the PSRF was $\sim 1.0$ for all parameters, suggesting convergence had been reached. Assessment of effective sample sizes for each parameter estimate was determined using the program Tracer v1.4 (Rambaut and Drummond 2007). The likelihood values converged to relatively stationary values after about 5,000 generations. Trees from each MrBayes run were combined and a burnin of 5000 trees $(25 \%$ of the total) was chosen, with a $>50 \%$ posterior probability consensus tree constructed from the remaining 15,002 trees. Average DNA sequence divergences within and between species were estimated using the program MEGA v. 4 (Kumar et al. 2008), with a composite likelihood distance applied under a HKY85 model of DNA sequence evolution (see Table 3 in Karanovic and Cooper 2012). 


\section{SYSTEMATICS}

\section{Order Harpacticoida Sars, 1903}

Family Miraciidae Dana, 1846

Genus Schizopera Sars, 1905

\section{Schizopera cooperi sp. nov.}

Figures 2-9

urn:Isid:zoobank.org:act:1C9F4DA9-A302-4A52-A8277AC897680DCF

\section{SYNONYMY}

Schizopera sp. 1: Karanovic and Cooper 2012: 175, Figure 38C, D.

\section{MATERIAL EXAMINED}

\section{Holotype}

Australia: Western Australia: female (WAM C47244), Hardey Deposit, about $45 \mathrm{~km} \mathrm{NW}$ of Paraburdoo, bore HAMB003, 22 ${ }^{\circ} 57^{\prime} 15.1$ 'S $117^{\circ} 18^{\prime} 37.9^{\prime \prime} E, 18$ September 2010, N.C.P. leg. Evelegh and D.S. Smith (dissected on one slide).

\section{Allotype}

Australia: Western Australia: male (WAM C47245), Hardey Deposit, about $45 \mathrm{~km} \mathrm{NW}$ of Paraburdoo, bore HAMB003, 22 57'15.1'S 117¹8'37.9'E, 18 September 2010, N.C.P. leg. Evelegh and D.S. Smith (dissected on one slide).

\section{Paratypes}

Australia: Western Australia: Hardy Deposit, about $45 \mathrm{~km} \mathrm{NW}$ of Paraburdoo, bore HAMB003, 22 ${ }^{\circ} 7^{\prime} 15.1^{\prime \prime S} 117^{\circ} 18^{\prime} 37.9^{\prime}$ E, 18 September 2010, leg. N.C.P. Evelegh and D.S. Smith: four males and three females together on one SEM stub (WAM C47246); four males, three females, and six copepodids together in ethanol (WAM C47247); and two females destroyed for DNA.

\section{DESCRIPTION}

Female (data from holotype and 6 paratypes). Total body length, measured from tip of rostrum to posterior margin of caudal rami (excluding caudal setae and appendages) from 340 to $395 \mu \mathrm{m}$ ( $375 \mu \mathrm{m}$ in holotype). Colour of preserved specimen yellowish. Nauplius eye not visible. Prosome comprising cephalothorax with completely fused first pedigerous somite, and 3 free pedigerous somites; urosome 6-segmented, comprising fifth pedigerous somite, genital doublesomite (fused genital and first abdominal somites) and 3 free abdominal somites. Short sclerotised joint between prosome and urosome only discernible on ventral side. Habitus (Figures 2A, 6A) cylindrical but not particularly slender, without distinct demarcation between prosome and urosome; prosome/urosome ratio about 1.1 (in dorsal view); greatest width at posterior end of cephalothorax but difficult to establish, with cephalothorax only slightly wider than genital double-somite. Body length/ width ratio about 4.6. Free pedigerous somites without pronounced lateral or dorsal expansions. Integument of all somites relatively well sclerotised, generally very smooth, without cuticular windows or pits. All somites (except cephalothorax) and caudal rami, besides other ornamentation, with several parallel rows of minute spinules (Figures 2A, 3A, 4A, 6, 8A, B). Hyaline fringe of all somites broad and mostly serrated, except smooth posterior end of cephalothoracic shield. Surface ornamentation of somites and caudal rami consisting of 69 pairs of pores and sensilla and 1 unpaired dorsal sensillum (numbered with Arabic numerals consecutively from anterior to posterior end of body, and from dorsal to ventral side in Figures 2A, 3A, 4A).

Rostrum (Figures 2A, 7A) long and clearly demarcated at base, reaching $2 / 3$ of second antennular segment, linguiform, with blunt tip, about twice as long as wide; ornamented with 2 sensilla dorsolaterally (no. 1).

Cephalothorax (Figures 2A, 6A, 7A, B) about 1.3 times as long as wide in dorsal view (without rostrum); represents $29 \%$ of total body length, tapering towards anterior end in dorsal view only in anterior third. Hyaline fringe of cephalothoracic shield wide and smooth. Surface of cephalothoracic shield ornamented with 1 unpaired dorsal sensillum (no. 16), 4 pairs of pores in anterior lateral corner (nos. 4, 7, 8, 9; see Figure 7B), and 29 pairs of long sensilla (nos. 2, 3, 5, 6, 10-15, 17-34); only 1 pair of sensilla at base of rostrum (no. 2; see Figure 7A); sensilla nos. 22 and 23 always very close to each other, as well as sensilla nos. 25 and 26; sensilla nos. 25-34 probably belong to first pedigerous somite incorporated into cephalothorax.

Pleuron of second pedigerous somite (first free) (Figures 2A, 6C) ornamented with 6 pairs of long sensilla (nos. 35-40); lateral pairs of sensilla nos. 38-40 serially homologous to pairs nos. 32-34 on first pedigerous somite respectively; other homologies difficult to define with any certainty, but pair no. 35 probably serially homologous to pair no. 31; hyaline fringe wide, smooth laterally but finely serrated dorsally.

Third pedigerous somite (Figures 2A, 6C) slightly shorter than second pedigerous somite, pleuron ornamented with 5 pairs of sensilla (nos. 41-45); recognising serially homologous pairs mostly easy $(41=36$, $42=37,43=38$, and $45=40$ ), except for sensilla pair no. 44 (probably not homologous to pair no. 39 on second pedigerous somite); hyaline fringe wide, smooth laterally but finely serrated dorsally.

Fourth pedigerous somite (Figures 2A, 6C) smaller and shorter than previous two somites, especially in dorsal view, pleuron ornamented with 5 pairs of sensilla (nos. $46-50), 4$ of them serially homologous to those on third pedigerous somite $(46=41,47=42,48=44,50=45)$ and 1 possibly serially homologous to that on second pedigerous somite $(49=39$ ?); hyaline fringe narrow (especially dorsally), smooth laterally but finely serrated dorsally. 


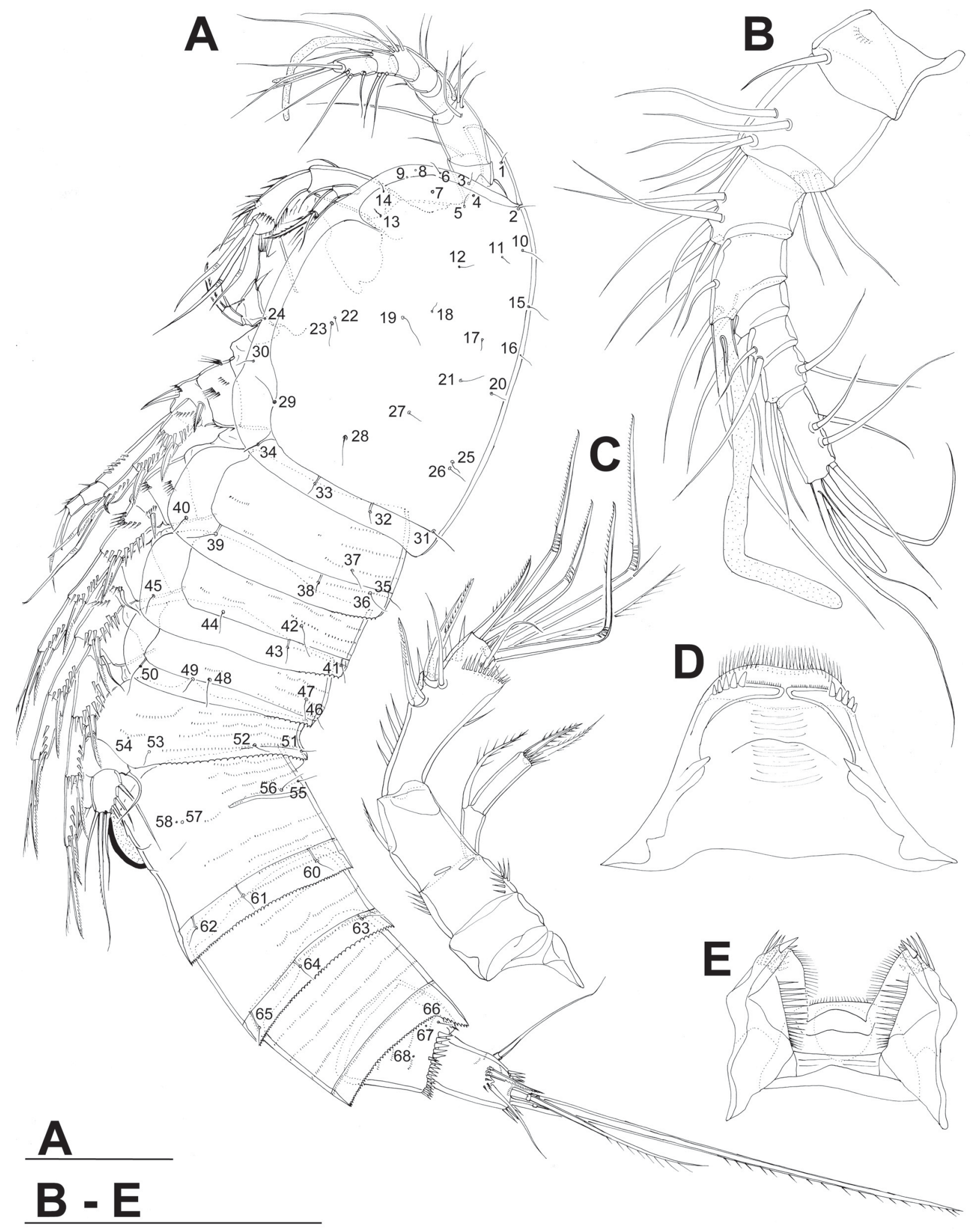

FIGURE 2 Schizopera cooperi sp. nov., line drawings, holotype female: A, habitus, lateral view; B, antennula, anterior view; C, antenna, posterior view; D, labrum, posterior view; E, paragnaths, anterior view. Arabic numerals numbering sensilla and pores consecutively from anterior to posterior end of body, and from dorsal to ventral side (excluding appendages). Scale bars $50 \mu \mathrm{m}$. 


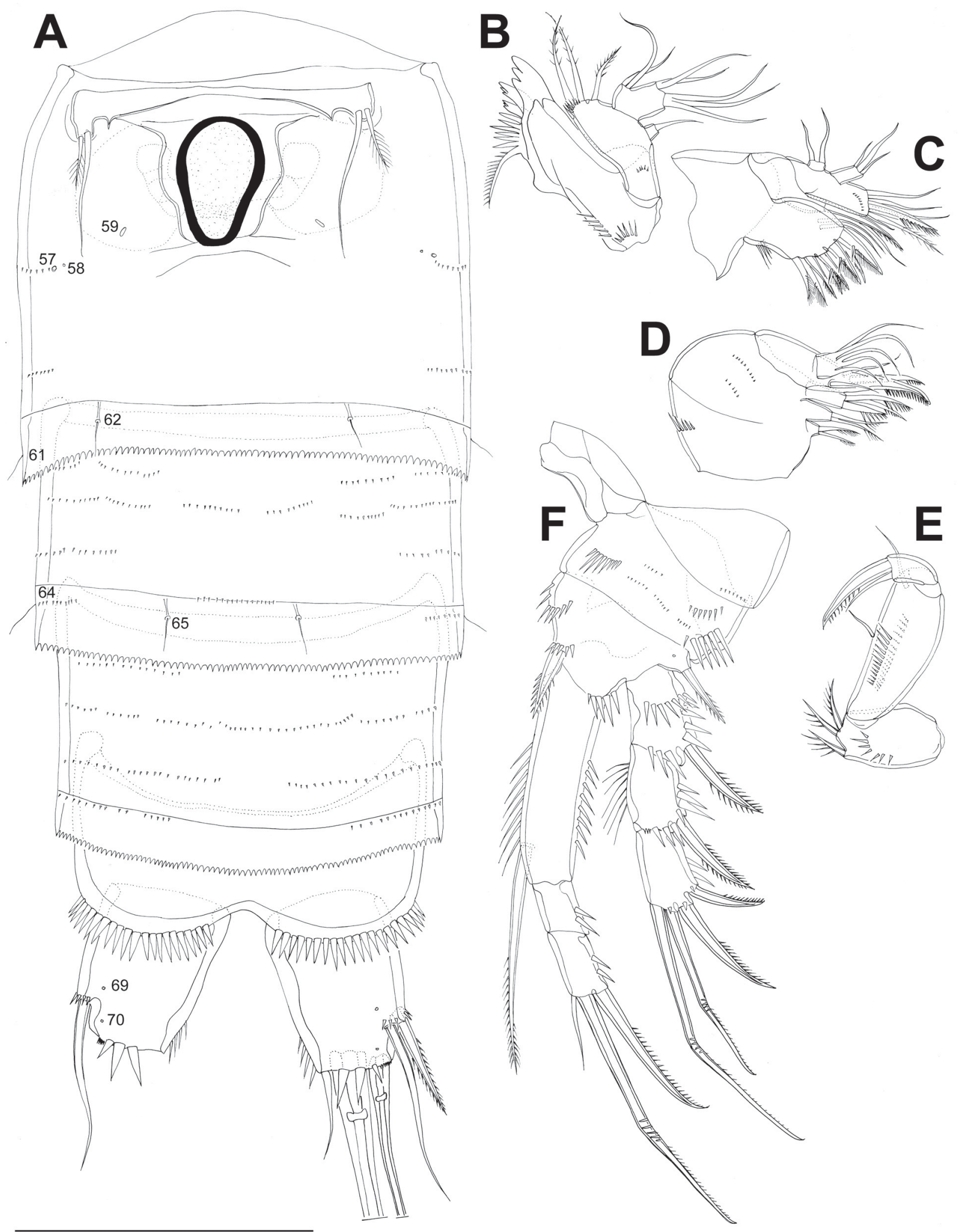

FIGURE 3 Schizopera cooperisp. nov., line drawings, holotype female: A, abdomen, ventral view (most setae omitted on right caudal ramus); $\mathrm{B}$, mandibula, anterior view; C, maxillula, posterior view; D, maxilla, posterior view; $E$, maxilliped, anterior view; F, first swimming leg, anterior view. Arabic numerals numbering sensilla and pores consecutively from anterior to posterior end of body, and from dorsal to ventral side (excluding appendages). Scale bar $50 \mu \mathrm{m}$. 


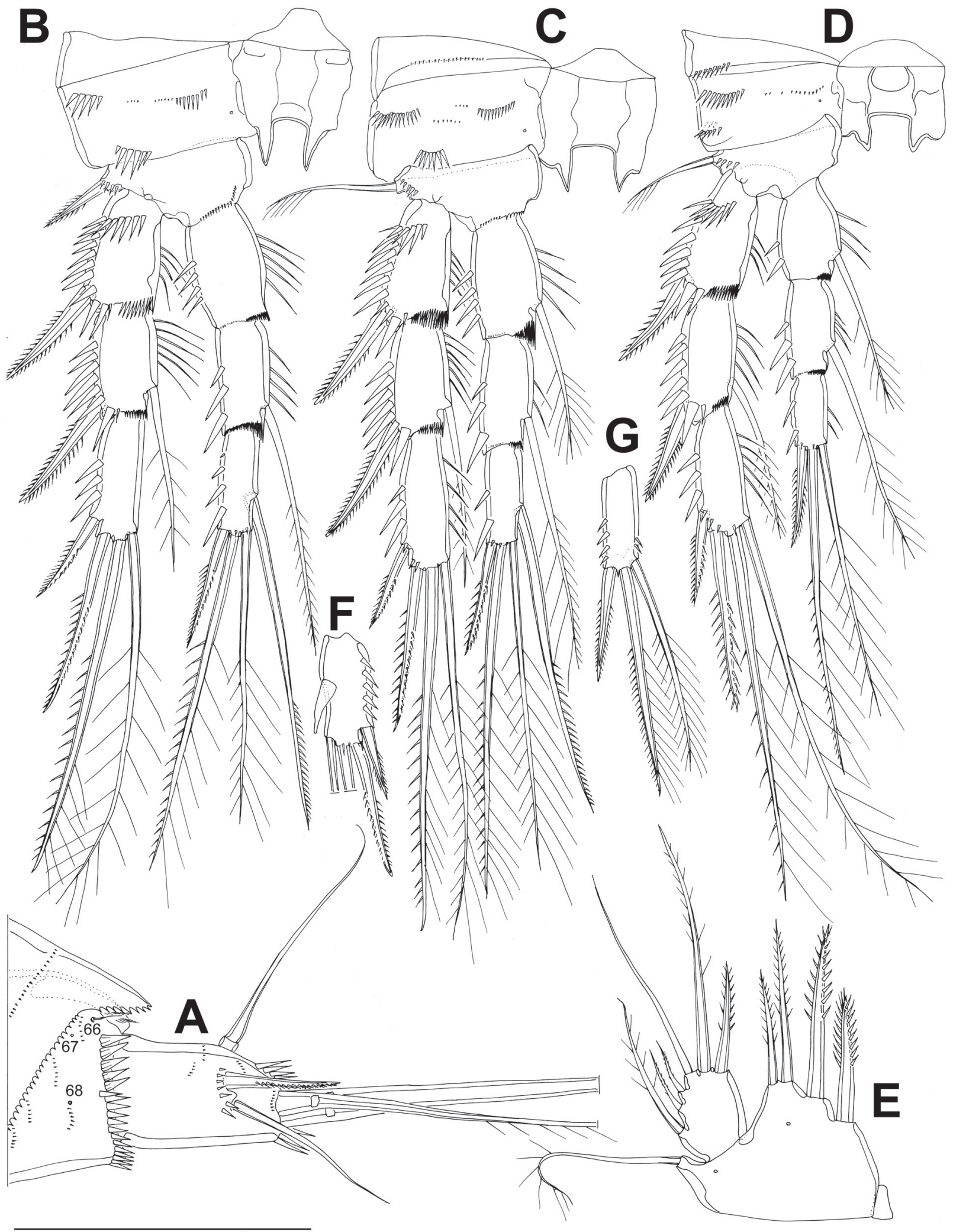

FIGURE 4 Schizopera cooperi sp. nov., line drawings, A-E, holotype female, F and G, allotype male: A, anal somite and left caudal ramus, lateral view; $B$, second swimming leg, anterior view; $C$, third swimming leg, anterior view; D, fourth swimming leg, anterior view; E, fifth leg, anterior view; F, third exopodal segment of third swimming leg, anterior view; G, third endopodal segment of third swimming leg, anterior view. Arabic numerals numbering sensilla and pores consecutively from anterior to posterior end of body, and from dorsal to ventral side (excluding appendages). Scale bar $50 \mu \mathrm{m}$. 


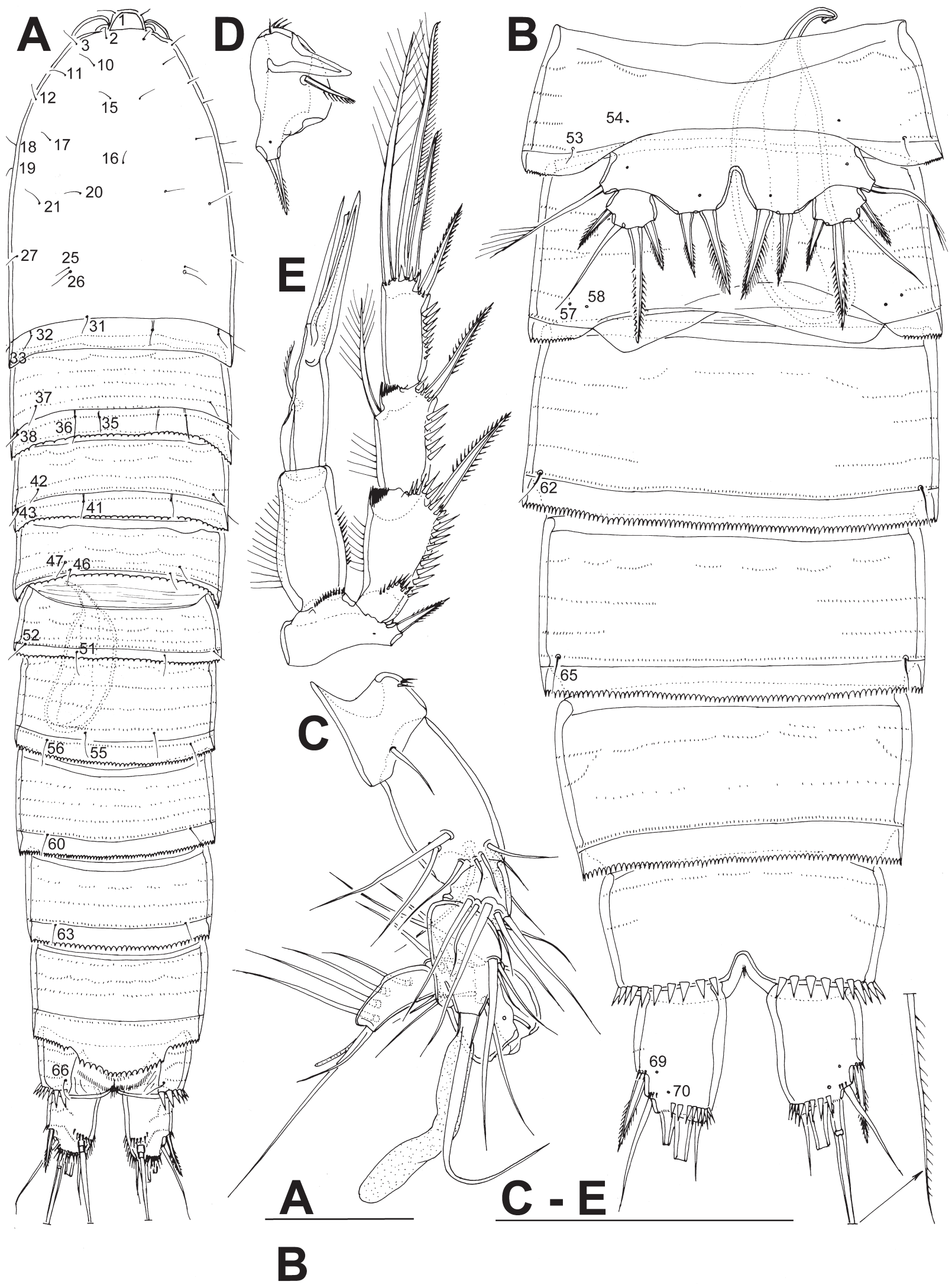

FIGURE 5 Schizopera cooperisp. nov., line drawings, allotype male: A, habitus, dorsal view; B, urosome, ventral view; C, antennula, anterior view; D, basis of first swimming leg, anterior view; E, basis, endopod, and exopod of second swimming leg, anterior view. Arabic numerals indicating sensilla and pores homologous to those in holotype. Scale bars $50 \mu \mathrm{m}$. 
Fifth pedigerous somite (first urosomite) (Figures 2A, 6C) about as long as fourth, ornamented with 3 pairs of posterior sensilla (nos. 51-53) and 1 pair of lateral pores (no. 54); serial homology of sensilla not obvious; hyaline fringe narrow and finely serrated.

Genital double somite (Figures 2A, 3A, 6D, 8A) about 0.8 times as long as wide (dorsal or ventral view), with visible internal ridge dorso-laterally (but no external suture) indicating original segmentation between genital and second abdominal somites; anterior part ornamented with 2 pairs of dorsal sensilla (nos. 55, 56), 2 pairs of small lateral pores (nos. 57, 58), and 1 pair of large ventral pores (no. 59); posterior part with 3 pairs of sensilla, 1 dorsal (no. 60), 1 lateral (no. 61), and 1 ventral (no. 62); serially homologous pairs of sensilla or pores (if any) not obvious; hyaline fringe wide and sharply serrated; each half of double somite with 4 parallel rows of minute spinules dorsally and laterally but not ventrally, with central smooth area that corresponds to internal suture and marks ancestral segmentation. Female genital complex (Figure 3A) with single copulatory pore partly covered by epicopulatory bulb (which serves also as copulatory duct), 2 small seminal receptacles placed inside large, paired, genital apertures; apertures with 2 ventral gonopores, each covered by reduced sixth leg. Epicopulatory bulb large, ovoid, strongly sclerotised, about 1.5 times as long as wide. Seminal receptacles very small, ovoid, both reaching anterior margin of epicopulatory bulb, about 0.6 times as long as epicopulatory bulb.

Third urosomite (Figures 2A, 3A, 6D, 8A) slightly narrower and significantly shorter than genital doublesomite, ornamented with 3 pairs of posterior sensilla (nos. 63-65), all obviously serially homologous to those on genital double-somite (i.e. $63=60,64=61,65=62$ ); ventral surface with more minute spinules than in genital double-somite; hyaline fringe broad and sharply serrated.

Fourth urosomite (preanal) (Figures 2A, 3A, 6E, 8A) slightly narrower than third urosomite, without sensilla or pores but with rows of minute spinules on all sides (only 2 posterior rows shortly interrupted ventrally); hyaline fringe sharply serrated, ventrally as wide as that in third urosomite but dorsally extended into wide and long pesudoperculum, which nearly reaches posterior margin of anal somite, with about 15 sharp teeth.

Anal somite (Figures 2A, 3A, 4A, 6E, 8B) cleft medially in posterior half, ornamented with 1 pair of large dorsal sensilla (no. 66), 2 pairs of lateral pores (nos. 67 and 68), posterior row of large spinules at base of each caudal ramus, and several short curved rows of minute spinules (mostly on dorsal and lateral surfaces); anal operculum short, reduced to very narrow and thin membrane at end of medial cleft dorsally, convex and situated anterior to dorsal sensilla, completely covered by pseudoperculum; anal sinus widely opened, with weakly sclerotised walls, without any chitinous projections, ornamented with 2 diagonal rows of slender spinules, represents $58 \%$ of somite width.
Caudal rami (Figures 3A, 4A, 6F, 8B) strongly sclerotised, about 1.5 times as long as greatest width in dorsal view, almost cylindrical (somewhat tapering towards caudal end but with almost straight inner margin), with space between them about $1 / 2$ of 1 ramus width; ornamented with 2 ventral pores in posterior half (nos. 69, 70), transverse row of 6 large spinules along posterior margin dorsally, 3 large spinules along posterior margin ventrally, diagonal row of large spinules at base of dorsal seta, longitudinal row of slender spinules along caudal end of inner margin, several larger and smaller spinules at base of lateral setae, and several short rows of minute spinules dorsally and laterally; armed with 6 elements (2 lateral, 1 dorsal, and 3 apical). Dorsal seta slender and apically pinnate, about 1.5 times as long as ramus, inserted at $2 / 3$ of ramus length, triarticulate at base (i.e. inserted on two pseudojoints). Lateral proximal spine stout, bipinnate, inserted at 3/4 of ramus length, 0.6 times as long as ramus. Lateral distal seta slender, smooth, inserted slightly ventrolaterally at $4 / 5$ of ramus length, about 0.9 times as long as ramus. Inner apical seta short and smooth, half as long as ramus. Principal apical setae with breaking planes; middle apical seta strongest, bipinnate at distal end, twice as long as unipinnate outer apical seta, and almost as long as urosome.

Antennula (Figures 2B, 7C) 8-segmented, approximately half as long as cephalothorax, with short aesthetasc on eighth segment fused to 2 apical setae, and large aesthetasc on fourth segment reaching significantly beyond tip of appendage and fused basally to equally long seta; setal formula: 1.9.7.3.2.3.4.7. Two lateral setae on seventh segment and 4 on eighth segment biarticulate (i.e. inserted on short pseudojoint). All setae smooth and slender, and most end apically with pore (except apical and subapical ones); apical pores only observable under scanning electron microscope. Length ratio of antennular segments, from proximal end and along caudal margin, $1: 1.5: 0.8: 0.6: 0.5: 0.4: 0.6$ $: 1.3$. First segment ornamented with short transverse row of small spinules ventro-medially, other segments unornamented.

Antenna (Figure 2C, 7D) comprising coxa, basis, 2 -segmented endopod, and much smaller but also 2-segmented exopod. Coxa very short, 0.6 times as long as wide, without ornamentation or armature. Basis and first endopodal segment partly fused along posterior surface. Basis also short and unarmed, about 0.7 times as long as wide, ornamented with several large spinules distally near inner margin, and diagonal row of large spinules on outer margin. First endopodal segment 1.5 times as long as wide and 1.8 times as long as basis, without ornamentation, armed with 1 short unipinnate lateral seta at middle. Second endopodal segment 1.9 times as long as first, more slender proximally, with 2 surface frills distally; lateral armature consists of 2 strong spines flanking small slender seta; apical armature consisting of 7 elements: 1 slender smooth seta, 1 unipinnate short spine, 4 geniculate setae, 
longest fused basally to another slender, unipinnate seta; all geniculate setae with minute spinules along outer (concave) margin distally. Ornamentation of second endopodal segment consists of longitudinal row of large spinules along anterior margin, 1 large spinule on posterior margin, and diagonal row of large spinules between lateral and apical armature elements. Both exopodal segments of about same width; first segment armed with 1 unipinnate subapical seta, unornamented; second segment about 1.5 times as long as first segment, ornamented with transverse apical row of slender spinules, armed apically with 1 slender seta and 1 strong spine, both bipinnate, seta about 1.4 times as long as spine and 1.2 times as long as second segment.

Labrum (Figure 2D) large, trapezoidal, rigidly sclerotised, with slightly concave cutting edge, ornamented apically and subapically with numerous slender spinules; subapical lateral spinules stronger than middle ones.

Paragnaths (Figure 2E) slightly smaller than labrum, also rigidly sclerotised, almost rhomboidal in shape, connected by medial trapezoidal lobe resembling labrum in shape, with numerous spinules along inner and apical margin (apical ones much more robust), as well as longitudinal row of spinules on anterior surface.

Mandibula (Figure 3B) with narrow cutting edge of coxa, armed with 3 complex teeth in ventral part (all tricuspidate), 6 simple teeth in dorsal part, and 1 unipinnate dorsalmost seta; coxa ornamented with two short rows of large spinules near base. Basis smaller and shorter than coxa, about 2.5 times as long as wide, armed with 3 bipinnate slender setae along inner margin; ornamented with transverse row of minute spinules at proximal part, as well as distal row of somewhat larger spinules at base of inner setae. Endopod 1-segmented, twice as long as wide (perception different in figure because of position), armed with 2 lateral and 5 apical smooth setae. Exopod very small but distinct segment, armed with single smooth apical seta.

Maxillula (Figure 3C) with large praecoxa, arthrite highly mobile, armed apically with 6 strong, unipinnate spines, and 2 dorsalmost unipinnate setae; laterally armed with 2 slender smooth setae and ornamented with short row of large spinules at base of arthrite. Coxa small, armed with 2 setae on inner margin; distal seta slender and smooth, proximal seta very strong, spiniform and unipinnate. Basis furnished with 1 strong, curved, and bipinnate spine, and 5 setae on inner margin, proximalmost seta minute, others as long as spine or longer; all setae except one smooth. Endopod 1-segmented, small, about twice as long as wide, armed with 3 apical smooth setae, central seta longest. Exopod also distinct but very small segment, half as long as wide, armed with 2 apical smooth setae.

Maxilla (Figures 3D, 7E) composed of syncoxa, basis and 1-segmented endopod. Syncoxa large, ovoid, with 3 endites, proximal and central ones armed with 2 subequal setae, distal armed with 2 setae and 1 spine, all unipinnate; ornamentation consists of transverse row of strong spinules on proximal part of outer margin and 2 diagonal rows of minute spinules on posterior surface. Basis much smaller than coxa, elongate, armed with 1 apical claw-like spine (partly fused to basis), 1 unipinnate and strong apical seta, and 2 slender and smooth lateral setae, 1 on anterior surface and 1 on posterior surface. Endopod very small, short and wide, armed with 5 smooth and slender setae apically and subapically, 2 of them fused basally to each other.

Maxilliped (Figures 3E, 7E) prehensile, 3-segmented, composed of coxobasis and 2-segmented endopod. Coxobasis 1.6 times as long as wide, cylindrical, ornamented with arched row of large spinules on anterior margin, armed with 3 unipinnate strong setae on inner (median) margin, all about half as long as coxobasis. First endopodal segment about 2.3 times as long as wide and 1.5 times as long as coxobasis, ornamented with 1 longitudinal row of large spinules proximally on anterior surface and 1 longer row of smaller spinules on posterior surface; armed with 2 slender and smooth setae, 1 centrally on inner margin and other subapically on posterior surface. Second endopodal segment smallest, only 0.36 times as long as first and twice as long as wide, armed apically with 1 claw-like unipinnate spine and 1 slender and smooth seta; spine nearly twice as long as second endopodal segment and 1.5 times as long as seta.

All swimming legs (Figure 2A) slender, short in comparison to body length and width, composed of small triangular praecoxa, large quadrate coxa, smaller basis, 3-segmented exopod, and 3-segmented endopod. Coxae in all legs connected with unornamented intercoxal sclerite. All exopodal and endopodal segments of about same length, except first endopodal segment of first leg which much longer.

First swimming leg (Figures 3F, 7F) with short and wide small intercoxal sclerite, concave at distal end and unornamented. Praecoxa unarmed, ornamented with posterior row of minute spinules. Coxa also unarmed, but ornamented with several short horizontal rows of spinules of various sizes on anterior surface, those near outer margin longest and strongest. Basis armed with 1 inner and 1 outer strong bipinnate spine, both about as long as inner margin of basis; ornamentation consists of several spinules at base of each spine, additional row of large spinules along distal margin between endopod and exopod, curved row of large spinules along inner margin, and 1 cuticular pore near base of outer spine (all on anterior surface). Exopod armed with single outer-distal spine on first and second segments, and with 2 outer spines and 2 apical geniculate setae on third segment; all exopodal segments ornamented with strong spinules along outer margin and subdistally, and additionally along inner margin of second segment; first exopodal segment with additional arched row of strong spinules on anterior surface proximally; inner geniculate seta on third segment only slightly shorter than entire exopod and about 1.5 times as long as outer geniculate seta. Endopod geniculate, with first segment 

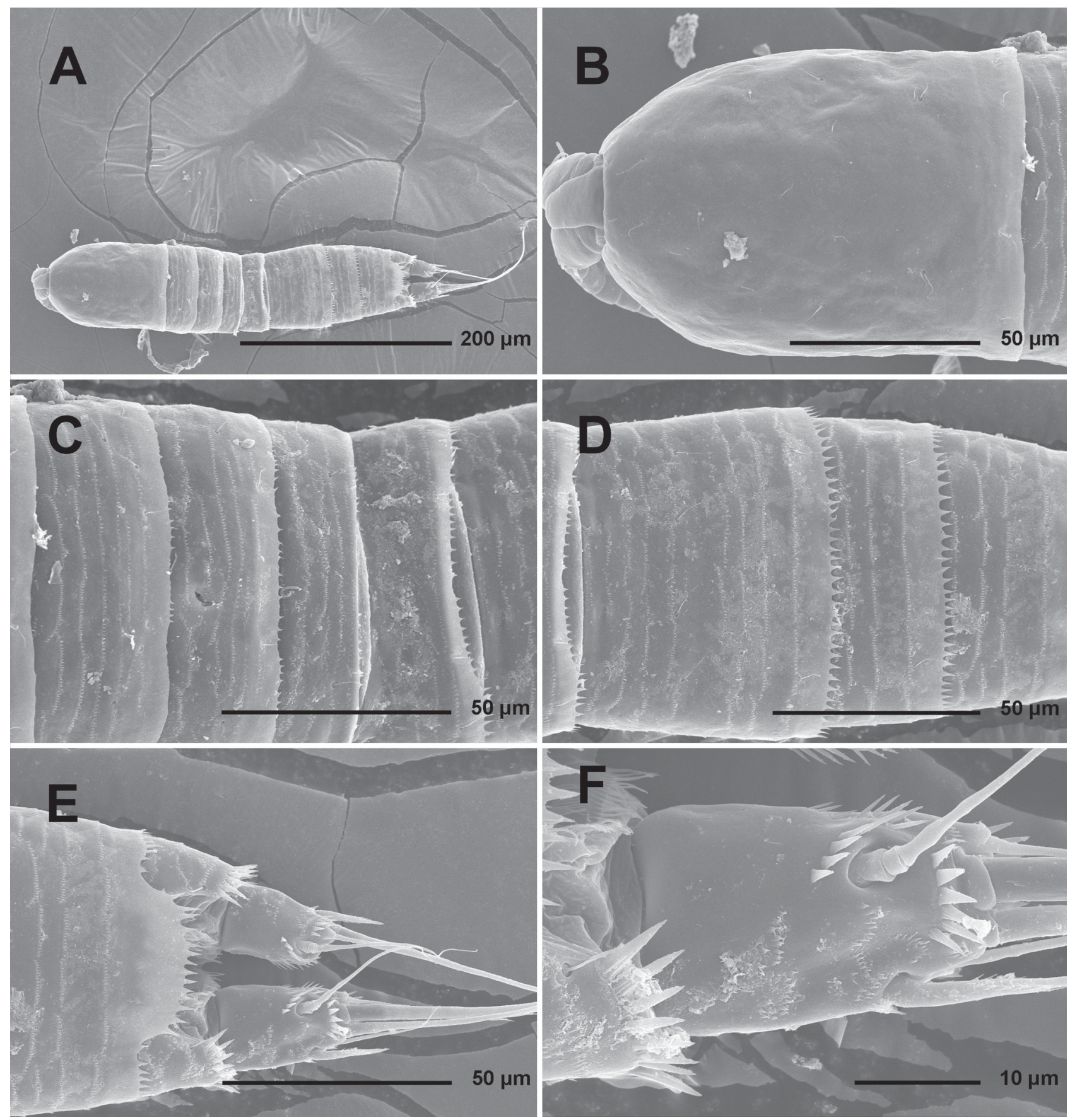

FIGURE 6 Schizopera cooperisp. nov., SEM micrographs, paratype female 1: A, habitus, dorsal view; B, cephalothoracic shield, dorsal view; C, pleurons of free pedigerous thoracic somites, dorsal view; D, genital double-somite and two subsequent abdominal somites, dorsal view; E, preanal and anal somites and caudal rami, dorsal view; F, left caudal ramus, dorsal view. Scale bars: $A=200 \mu \mathrm{m} ; \mathrm{B}-\mathrm{E}=50 \mu \mathrm{m} ; \mathrm{F}=10 \mu \mathrm{m}$.

0.9 times as long as entire exopod, 4.2 times as long as second endopodal segment, and about 3.6 times as long as wide; small sclerotised beak present proximally on inner margin of first segment, hidden behind inner spine of basis; third endopodal segment about 1.3 times as long as second endopodal; endopodal armature consists of 1 strong and long inner seta on first segment (inserted at about 4/5), and 3 setae on third segment (innermost slender and smooth, middle longest and geniculate, outermost spiniform seta (or spine?), 0.6 times as long as middle one); endopodal ornamentation consists of strong spinules along outer margin of all segments, and also along inner margin of first segment.

Second swimming leg (Figure 4B) with even smaller praecoxa than in first leg, unarmed and unornamented. Coxa ornamented with single cuticular pore, 3 short 

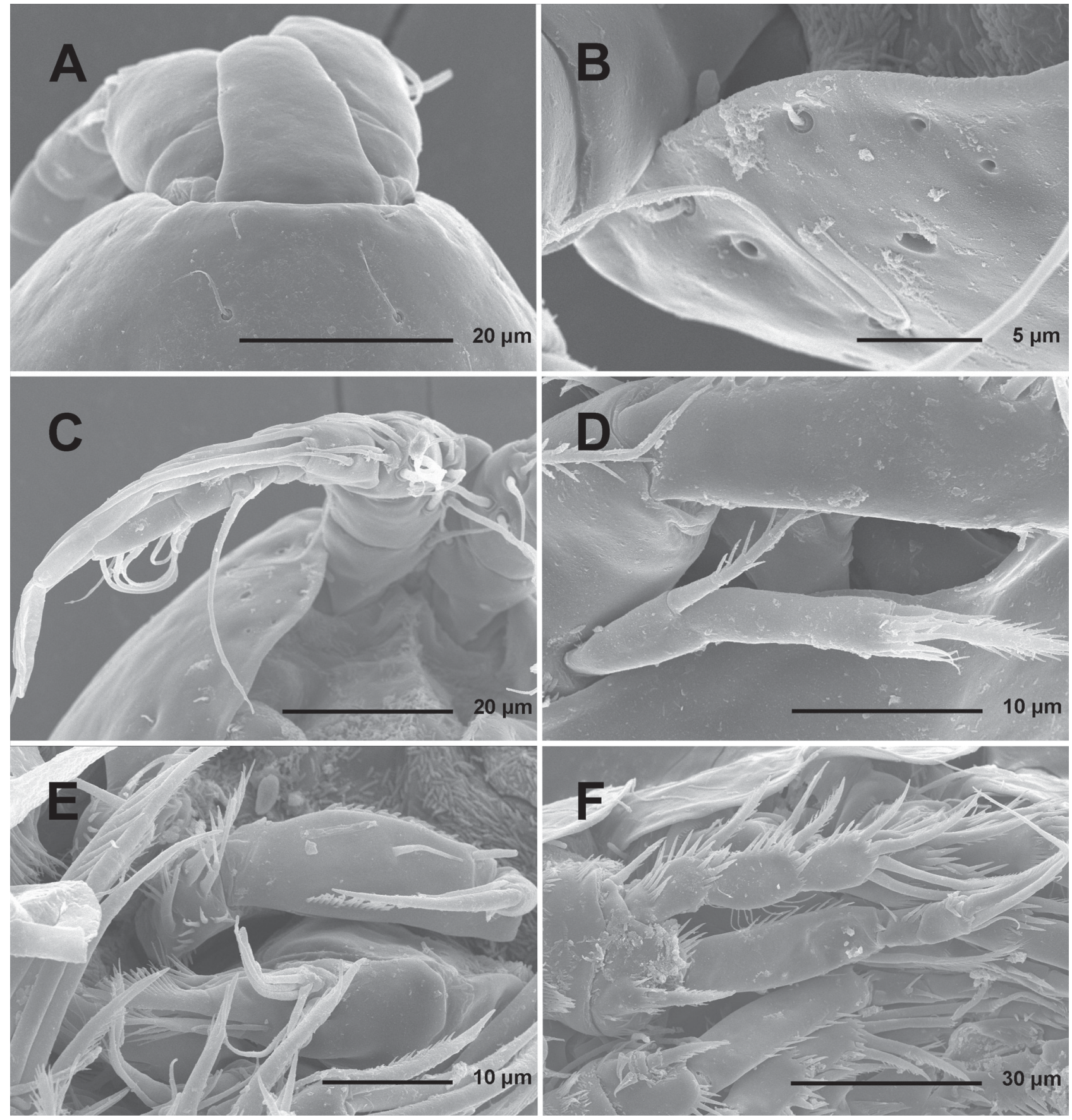

FIGURE 7 Schizopera cooperi sp. nov., SEM micrographs, A, paratype female 1, B-F, paratype female 2: A, anterior part of cephalothorax and rostrum, dorsal view; B, anterolateral part of cephalothoracic shield, ventral view; C, antennula, ventral view; D, exopod of antenna, ventral view; E, maxilla and maxilliped, ventral view; F, first swimming leg, ventral view. Scale bars: $A$ and $C=20 \mu \mathrm{m} ; B=5 \mu \mathrm{m} ; \mathrm{D}$ and $\mathrm{E}=10 \mu \mathrm{m} ; \mathrm{F}=30 \mu \mathrm{m}$.

horizontal rows of large spinules, and several minute spinules between two proximal rows, all on anterior surface. Intercoxal sclerite with paired, pointed, distal protrusions. Basis armed only with outer bipinnate spine, ornamented with small spinules at base of outer spine and with minute spinules along distal margin at base of endopod. Distal inner corners of first and second exopodal and endopodal segments with serrated hyaline frills. All exopodal and endopodal segments ornamented with strong spinules on outer margins; first and second segments also with less strong spinules along inner margins. Exopod armed with outer-distal spine on first and second segments, inner seta on second segment, 2 outer spines and 2 apical setae on third segment; all spines and setae strong, spiniform, and bipinnate; outer apical seta on third segment looks like transitional stage 

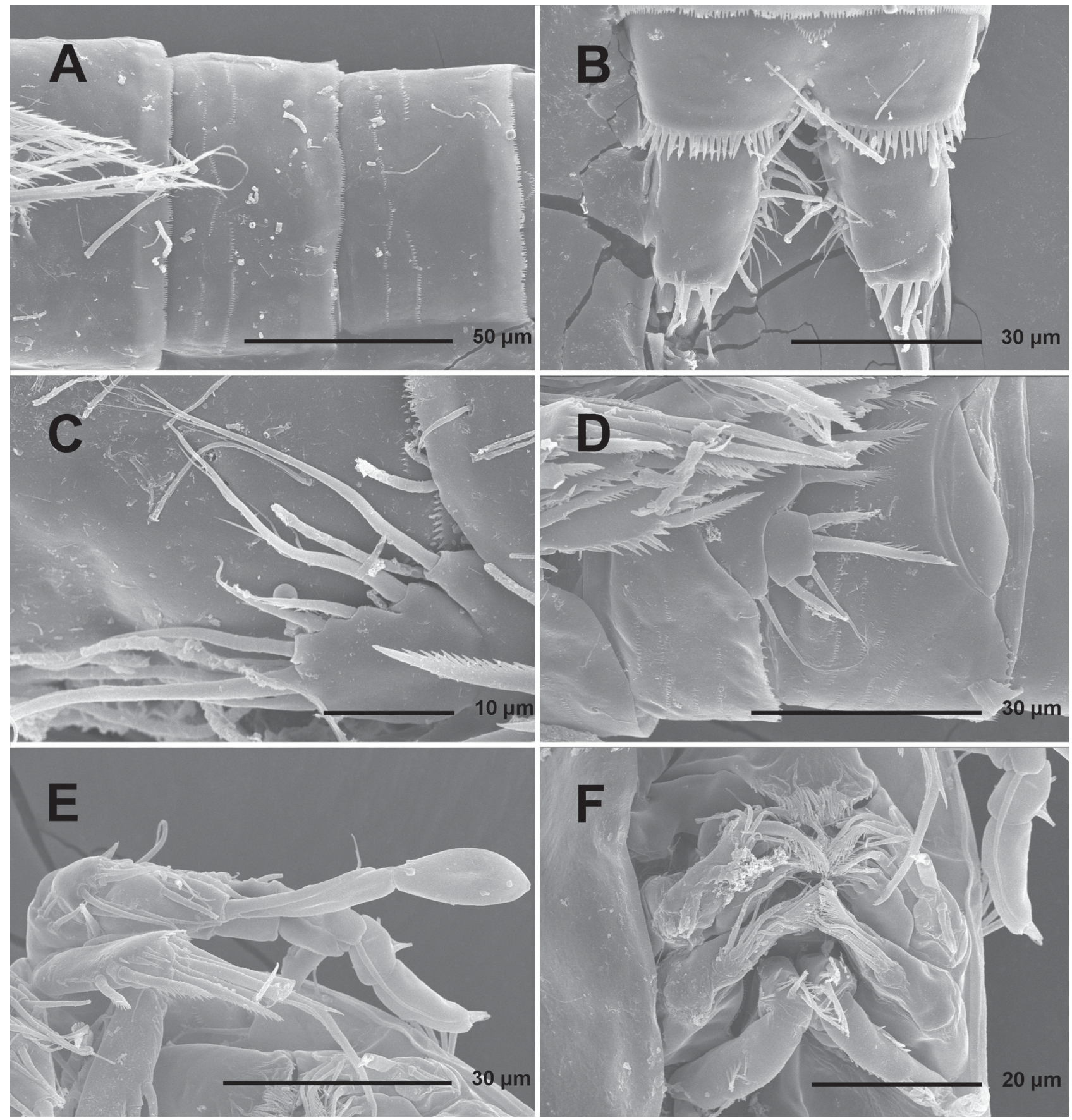

FIGURE 8 Schizopera cooperi sp. nov., SEM micrographs, A and B paratype female 2, C, paratype female 3, D-F, paratype male 1: A, posterior part of genital double-somite and two subsequent abdominal somites, ventral view; $B$, anal somite and caudal rami, ventral view; C, exopod of fifth leg, lateral view; D, fifth and sixth legs, ventro-lateral view; $E$, distal tips of antennula and antenna, ventro-lateral view; F, mouth appendages, ventro-lateral view. Scale bars: $A=50 \mu \mathrm{m} ; B, D, E=30 \mu \mathrm{m} ; C=10 \mu \mathrm{m} ; F=20 \mu \mathrm{m}$.

between spine and seta, with outer margin furnished with short spinules and inner margin with slender long spinules. Endopod as long as exopod, armed with single inner seta on second segment, and 4 elements on third segment: outer-distal short spine, 2 apical long setae, and 1 inner strong seta (inserted at 2/3).

Third swimming leg (Figure 4C) very similar to second, except basis armed with outer slender seta instead of spine, and praecoxa ornamented with distal row of minute spinules; also pointed processes on intercoxal sclerite less sharp than in second leg.

Fourth swimming leg (Figure 4D) similar to third leg, except inner seta missing on third endopodal segment, endopod only about 0.8 times as long as exopod, 


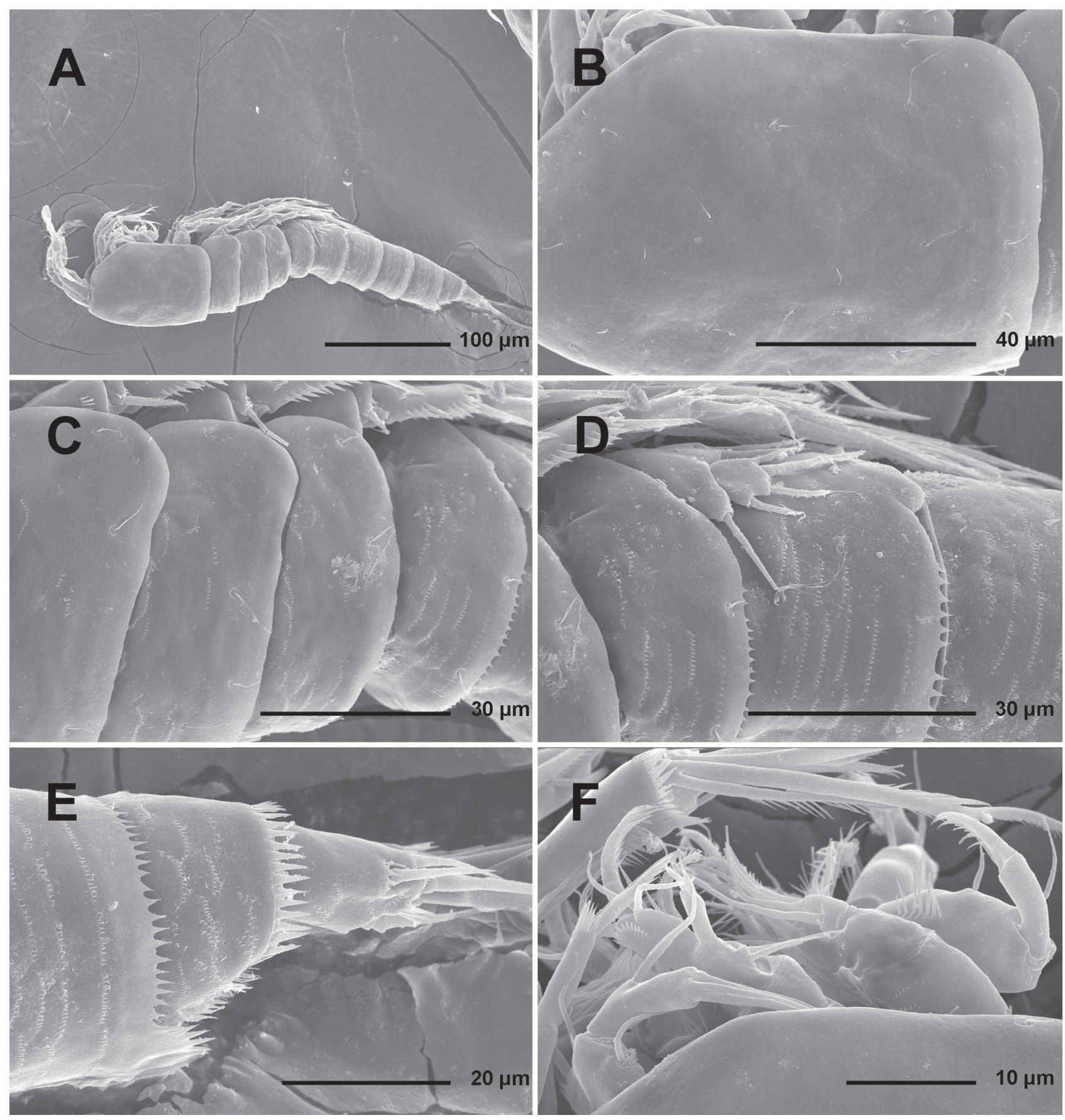

FIGURE 9 Schizopera cooperi sp. nov., SEM micrographs, paratype male 2: A, habitus, lateral view; B, cephalothoracic shield, lateral view; C, pleurons of free pedigerous thoracic somites, lateral view; D, fifth pedigerous and genital somites, lateral view; $E$, anal somite and caudal rami, lateral view; F, mouth appendages, lateral view. Scale bars: $A=100 \mu \mathrm{m} ; B=40 \mu \mathrm{m} ; C$ and $D=30 \mu \mathrm{m} ; E=20 \mu \mathrm{m} ; F=10 \mu \mathrm{m}$.

spinules on praecoxa larger, and pointed processes on intercoxal sclerite even less sharp.

Fifth leg (Figures 4E, 8C) biramous, composed of large baseoendopod and small exopod, with division line visible on both posterior and anterior surface. Baseoendopod with outer basal smooth seta arising from relatively short setophore, with one cuticular pore on anterior surface at base of setophore. Endopodal lobe almost triangular, extending to $3 / 4$ of exopod in length, ornamented with small cuticular pore on anterior surface, armed with 4 very stout, spiniform, elements ( 2 inner ones probably spines, 2 outer ones probably spiniform setae); length ratio of endopodal armature elements, from inner side, $1: 1.4: 1.3: 0.9$. Exopod ovoid, about 1.3 times as long as maximum width, unornamented, armed with 6 elements: 2 inner 
apical strong and bipinnate, outer apical smooth and slender, distal and central outer short and bipinnate, and proximal outer long and bipinnate; length ratio of exopodal armature elements, from inner side, $1: 2.3: 2$ $: 0.5: 0.6: 1.4$.

Sixth leg (Figure 3A) indistinct, very small cuticular plate, covering gonopore, armed with 1 very small spine, fused basally to plate, and 2 setae; inner seta slender and smooth, about 2.4 times as long as outer bipinnate seta.

Male (data from allotype and 8 other paratypes). Body length ranges from 354 to $390 \mu \mathrm{m}$ ( $385 \mu \mathrm{m}$ in allotype). Habitus (Figures 5A, 9A) more slender than in female, but also cylindrical, and with similar proportions of prosome/urosome, and cephalothorax/genital somite. Body length/width ratio about 5.05. Ornamentation of prosomites (Figures 5A, 9B, C), colour, and nauplius eye as in female.

Genital somite (Figures 5A, B, 8D, 9D) twice as wide as long. Single, completely formed, longitudinally placed spermatophore inside first 2 urosomites in most specimens (also visible in allotype). Ventral pair of pores (no. 59) absent, but all other ornamentation elements present, including lateral pores nos. 57 and 58.

Other abdominal somites (Figures 5A, B, 9D, E) similar to female, except slightly better ornamented with minute spinules on ventral surface.

Caudal rami (Figures 5A, B, 9E) without any difference from those in female.

Antennula (Figures 5C, 8E10C, 11B) half as long as cephalothorax, strongly prehensile and 9-segmented (basically female sixth segment subdivided), with geniculation between fourth and fifth and seventh and eighth segments. Segments that participate in geniculation strengthened with cuticular plates along anterior surface, largest ones being on sixth segment. Aesthetascs as in female, on fourth and last segments; that on fourth segment somewhat wider than in female. First 2 and last 2 segments similar to female. Setal formula: 1.9.7.5.1.0.1.4.6. Most setae smooth and with pore on top; same setae biarticulated as in female.

Antenna (Figure 8E), labrum (Figure 8F), mandibula (Figures 8F, 9F), maxillula (Figures 8F, 9F), maxilla (Figures 8F, 9F), maxilliped (Figures 8F, 9F), exopod and endopod of first swimming leg (Figure 9A), exopod of second swimming leg (Figure 5E), first 2 endopodal segment of third swimming leg, and fourth swimming leg (Figure 9A) similar to female.

First swimming leg (Figure 5D) with modified basis, inner margin very rigidly sclerotised, with spiniform smooth distal process. Inner spine on basis smaller than in female, without spinules at its base, inserted more proximally, and slightly longer than spiniform process of basis.

Second swimming leg (Figure 5E) with transformed endopodal second and third segments. Second segment with part of inner margin protruded as rounded indistinct lobe, without ornamentation on surface; inner seta shorter than in female, unipinnate and slender. Third segment completely modified; inner seta absent and 2 ancestral apical setae transformed into smooth spiniform armature elements of about same length; outer one stronger and with abruptly sharpened tip. Ancestral outer spine completely fused to somite, transformed into very strong and smooth thorn, which only slightly longer than ancestral apical elements. As result of these transformations, third segment medially cleft.

Third swimming leg (Figure 4F, G) with very characteristic element on anterior surface of third exopodal segment (Figure 4F) swollen at basal part, with pore on tip, inserted at $2 / 5$ and close to inner margin, not reaching distal margin of third segment; this structure probably represents very enlarged tubular pore. Third endopodal segment without inner seta (Figure 4G).

Fifth legs (Figures 5B, 8D, 9D) with basally fused baseoendopods but ornamented with 2 cuticular pores on anterior surface as in female. Endopodal lobe much smaller and shorter, trapezoidal, extending to middle of exopod in length, armed with 2 very strong apical spines; inner spine about 1.3 times as long as outer one. Exopod about 0.8 times as long as its maximum width, demarcated basally on both anterior and posterior surface, armed with only 4 elements; 2 short outer elements, which present in all examined females, not observed in any male specimens; length ratio of exopodal armature elements, from inner side, 1: $2.2: 2$ $: 1$.

Sixth legs (Figures 5B, 8D, 9D) pair of small and short cuticular plates, without armature or ornamentation; right better demarcated at base and probably functions as genital flap.

\section{VARIABILITY}

In addition to the slight variability in body length (see above), several other features were observed as variable. One paratype female has a deformed right caudal ramus (Figure 6E), without inner and central apical setae, and with distal lateral seta inserted more dorsally than in normal condition. One paratype male is missing one sensillum (no. 45) on the third pedigerous somite (Figure 9C), as well as three ventro-lateral pores (nos. 54, 57, 58) on the first two urosomites (Figure 9D). Posterior dorsal pair of sensilla on the cephalothoracic shield (no. 31 ) is slightly asymmetrical in the allotype male (Figure $5 \mathrm{~A})$, although it is symmetrical in all other examined specimens (see Figure 6B). Absence of inner seta on the third endopodal segment of third swimming leg (Figure 4G) may be part of individual specimen variability, rather than sexual dimorphism, but more specimens would have to be examined to confirm this.

\section{ETYMOLOGY}

The species is named in honour of Professor Steven J.B. Cooper from the South Australian Museum in Adelaide, who supervised sequencing for this study and helped with molecular cladistic analyses. The name is a noun in the genitive singular. 


\section{DISCUSSION}

Morphological affinities of the new species clearly lie with $S$. weelumurra, a species described from a single female collected some $65 \mathrm{~km}$ north of Tom Price (about $100 \mathrm{~km} \mathrm{NE}$ of the type locality of $S$. cooperi), and not with the geographically much closer $S$. roberiverensis (easternmost population about $45 \mathrm{~km} \mathrm{SE}$ of the type locality of $S$. cooperi; see Figure 1). The new species differs from $S$. roberiverensis by a great number of morphological features, the most important being: shorter caudal rami; the third endopodal segment of first, second (in female only), and third legs with inner seta present (absent in $S$. roberiverensis); the second exopodal segment of second and third legs with inner seta present (absent in $S$. roberiverensis); much longer seta on the first endopodal segment of first leg; six setae present on the exopod of the female fifth leg (five in S. roberiverensis); exopod of the female fifth leg distinct segment (partly fused to basaeoendopod in $S$. roberiverensis); and two setae present on the female sixth leg (only one in $S$. roberiverensis). Karanovic (2006) reported some differences between the easternmost population of $S$. roberiverensis (from bore TPB2-1; see Figure 1) and from the type locality (some $250 \mathrm{~km}$ apart), but both populations showed a great variability with many asymmetries and abnormalities among animals. Therefore, it was impossible to confidently separate the two populations on morphological evidence alone, and obtaining fresh samples for molecular analyses should be an important goal of any future studies of this genus in Australia.

Morphological differences between $S$. cooperi and $S$. weelumurra are minute in comparison to those between $S$. roberiverensis and these two species. For example, the two species share the same armature formula of all swimming legs, as well as that of the fifth and sixth legs. The new species can be distinguished by a longer innermost armature element on the fifth leg endopod, longer slender apical seta on the fifth leg exopod, wider anal sinus, and larger teeth on the pesudoperculum. These are all female characters because males are still unknown for $S$. weelumurra. We have no doubt that the two are separate, although closely related species, but obtaining additional samples of $S$. weelumurra for morphological studies should be a priority. Equally important is getting fresh material for molecular studies, now that we have sequences for a significant number of Australian congeners.

DNA was extracted and the COI fragment successfully PCR-amplified from 43 copepod specimens (Table 1). All sequences were translated into protein using MEGA and were shown to have no evidence of stop codons, ambiguities or insertions/deletions indicative of non-functional copies of COI. BLAST analyses of GenBank revealed that the obtained sequences are copepod in origin and not contaminants. Average pairwise distances between species were found to be very high, with the lowest divergence $(15.4 \%)$ between $S$. leptafurca and S. uranusi. There was evidence for multiple divergent $(12.3 \%$ average sequence divergence; $12-16.5 \%$ divergence between haplotypes) lineages within the species $S$. akation but the question remains whether these lineages represent the presence of cryptic species, or are divergent mtDNA sequences within a species. Our cladistics analysis (Figure 10) supported the presence of at least 11 genetically divergent ingroup lineages and all six of the multi-sample lineages were supported with posterior probabilities of 1 . A sister group relationship of $S$. uranusi with $S$. leptafurca was strongly supported, as well as the monophyly of a group comprising $S$. uranusi, S. leptafurca, $S$. emphysema, and $S$. cooperi (the former showing a posterior probability of 1, the latter of 0.99). There is also a strongly supported sister group relationship of $S$. analspinulosa s. str. and $S$. analspinulosa linel (posterior probability of 0.94). Although morphological evidence would suggest a relatively close relationship of $S$. kronosi, $S$. analspinulosa $S$. str., and S. analspinulosa linel, posterior probabilities for this arrangement were very low $(<0.5 \%)$. This lack of support is likely to be the result of the low phylogenetic resolution of the COI gene in basal nodes of the tree, possibly due to saturation at third codon positions. The one specimen that did not match our morphospecies (7439; preliminary identification as $S$. uranusi) formed a separate lineage and is likely to represent another uncharacterised species of Schizopera.

It is interesting to note that the two congeners from the Pilbara (arrows in Figure 10) do not seem to be very closely related, in fact, they have much closer relatives in the neighbouring Yilgarn region. This would imply that their presence in the subterranean waters of the Pilbara region is a consequence of two independent colonisation events. Whatever the status of the easternmost population of $S$. roberiverensis, there is no doubt that the disjunct populations of $S$. roberiverensis are all closely related. A similar disjunct pattern of distribution is present between the closely related $S$. weelumurra and $S$. cooperi (Figure 1) and the known localities of the two species are in separate drainage systems. Therefore, it seems that the best colonisation model for Pilbara Schizopera species/populations would be that of subterranean habitat invasion from ancestors that had a wider distribution in surface water habitats. This hypothesis of surface invasion is in stark contrast to the evolutionary history of the genus in the neighbouring Yilgarn region, where Karanovic and Cooper (2012) were able to demonstrate an active dispersal upstream for a number of species (i.e. ancestors of Recent species were probably already stygobionts, possibly colonising from the marine interstitial along palaeochannels).

The suggested differences in the colonisation history of the only stygobitic copepod genus to occur in both the Pilbara and Yilgarn may provide clues to the reasons for the observed stygofaunal differences between the two regions. However, a much broader sampling of taxa to derive molecular phylogenies is necessary to answer 


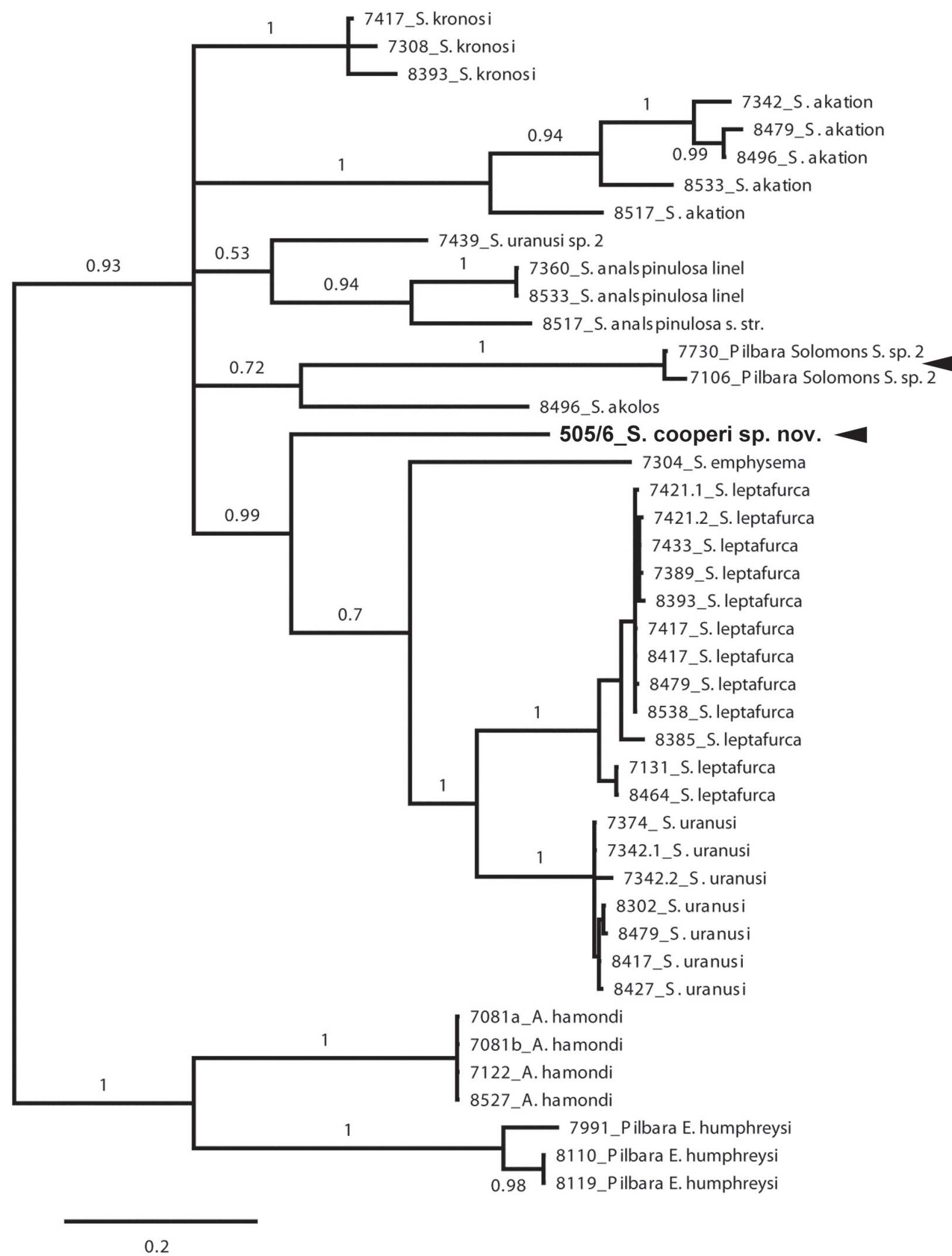

FIGURE 10 MrBayes 50\% posterior probability cladogram based on mtCOI sequences of eight Schizopera species from the Yilgarn region, S. cooperi sp. nov., one as yet unidentified species from the Pilbara region (S. sp. 2), and two outgroup taxa from the family Canthocamptidae (Australocamptus hamondi Karanovic, 2004 from the Yilgarn and Elaphoidella humphreysi Karanovic, 2006 from the Pilbara). Posterior probabilities shown above branches. Arrows point to two Schizopera species from the Pilbara region. 
these interesting questions with confidence, and that is why collection of more Schizopera species (including those from surface water habitats, like the provisionally identified S. clandestina from Lake Gardner and Lake Coyrecup) is so important.

\section{KEY TO AUSTRALIAN SPECIES OFTHE GENUS SCHIZOPERA}

This key is based on female characters, because males of $S$. kronosi, $S$. oldcuei, and $S$. weelumurra are as yet unknown. The record of the provisionally identified $S$. clandestina by Halse et al. (2002) needs to be verified, and this species is not included in the key.

1. Urosomites and caudal rami ornamented with dense cover of long spinules

Spinules on somites minute and much more sparse.

2. Preanal somites without spinules; endopod of fourth leg 2-segmented S. akolos

Urosomites ornamented with 2-4 rows of minute triangular spinules; endopod of fourth leg 3-segmented

3. Caudal rami without large spinules along anterior part of inner margin 4

Caudal rami with large spinules along anterior part of inner margin S. akation

4. Third endopodal segment of first, second, and third leg without inner seta .... S. roberiverensis

This segment with inner seta present ........... 5

5. Innermost element on fifth leg endopod slightly longer than outermost S. cooperi

Innermost element on this segment much shorter than outermost S. weelumurra

6. Two dorsalmost spinules on anal somite enlarged

All spinules on anal somite of about same size

7. Inner apical setae on third endopodal segment of second to fourth legs well-developed ........ 8

These setae minute and smooth ........ S. kronosi

8. Coxa of first leg with 3 outer groups of large spinules on anterior surface; 2 distal outer elements on fifth leg exopod as strong as proximal one S. a. analspinulosa

Only 2 groups of large spinules on coxa of first leg; 2 distal outer elements on fifth leg exopod much more slender than proximal one S. analspinulosa linel

9. Caudal rami widest at anterior margin (where attached to somite) 10

Caudal rami widest at middle, with inflated appearance S. emphysema

10. Caudal rami conical or cylindrical 11

Caudal rami constricted at middle S. leptafurca

11. Caudal rami less than four times as long as wide 12

Caudal rami more than four times as long as wide S. jundeei

12. Outer apical seta on caudal rami much longer than ramus ...................................................... 13

This seta about as long as ramus ...... S. oldcuei

13. Caudal rami more than twice as long as wide 14

Caudal rami less than twice as long as wide 15

14. Caudal rami almost cylindrical, proximal outer and dorsal setae at $2 / 3$ of ramus length S. uramurdahi

Caudal rami more conical, proximal outer and dorsal setae at midlength S. uranusi

15. Caudal rami slender when compared to anal somite, about 1.7 times as long as wide; baseoendopod of fifth leg ovoid, exopod armed with 5 elements S. depotspringsi

Caudal rami broad, 1.4 times as long as wide; baseoendopod of the fifth leg triangular, exopod armed with 6 elements S. austindownsi

\section{ACKNOWLEDGEMENTS}

The authors are deeply indebted to Dr Stefan Eberhard, Subterranean Ecology Environmental Services, for making Schizopera material available and for partly funding molecular analyses. The following former staff of Subterranean Ecology Pty are acknowledged for their help in the field and laboratory: Ms Giulia Perina, Ms Natalie Krawczyk, Mr Peter Bell, and Mr Shae Callan. We also are very grateful to Dr Tessa Bradford and Ms Kathleen Saint (South Australian Museum) for carrying out the PCR and sequencing analyses, and Ms Saint is also greatly acknowledged for developing nested primers that were used in combination with universal primers for COI gene amplification. Special thanks go to Prof. Steven J.B. Cooper (South 
Australian Museum) for supervising sequencing and helping with molecular cladistic analyses. Financial support to the senior author came from Brain Pool and NIBR grants (both in Korea) and Subterranean Ecology Pty Ltd, while the necessary facilities were provided by the Hanyang University in Seoul. Two anonymous reviewers are acknowledged for many constructive remarks.

\section{REFERENCES}

Adamowicz, S.J., Menu-Marque, S., Hebert, P.D.N. and Purvis, A. (2007). Molecular systematics and patterns of morphological evolution in the Centropagidae (Copepoda: Calanoida) of Argentina. Biological Journal of the Linnean Society 90: 279-292.

Apostolov, A. (1982). Genres et sous-genres nouveaux de la famille Diosaccidae Sars et Cylindropsyllidae Sars, Lang (Copepoda, Harpacticoidea). Acta Zoologica Bulgarica 19: 37-42.

Bodin, P. (1997). Catalogue of the new marine Harpacticoid Copepods (1997 Edition). Documents de travail de l'Institut royal des Sciences naturelles de Belgique 89: 1-304.

Boxshall, G.A. and Halsey, S.H. (2004). An introduction to copepod diversity. The Ray Society: London.

Boxshall, G.A. and Jaume, D. (2000). Making waves: the repeated colonization of freshwater by copepod crustaceans. Advances in Ecological Research 31: 61-79.

Bradford, T., Adams, M., Humphreys, W.F., Austin, A.D. and Cooper, S.J.B. (2010). DNA barcoding of stygofauna uncovers cryptic amphipod diversity in a calcrete aquifer in Western Australia's arid zone. Molecular Ecology Resources 10: 41-50.

Folmer, O., Black, M., Hoeh, W., Lutz, R. and Vrijenoek, R. (1994). DNA primers for amplification of mitochondrial cytochrome c oxidase subunit 1 from diverse metazoan invertebrates. Molecular Marine Biology and Biotechnology 3: 294-299.

Gurney, R. (1928). Some Copepoda from Tanganyika collected by Mr S.R.B. Pask. Proceedings of the Zoological Society of London 22: 317-332.

Halse, S.A., Cale, D.J., Jasinska, E.J. and Shiel, R.J. (2002). Monitoring change in aquatic invertebrate biodiversity: sample size, faunal elements and analytical methods. Aquatic Ecology 36: 395-410.

Hebert, P.D.N., Cywinska, A., Ball, S.L. and deWaard, J.R. (2003). Biological identifications through DNA barcodes. Proceedings of the Royal Society of London 270: 313-321.

Huelsenbeck, J.P. and Ronquist, F. (2001). MRBAYES: Bayesian inference of phylogeny. Bioinformatics 17 : 754-755.

Humphreys, W.F. (2000). Background and glossary. In Wilkens, H., Culver, D.C. and Humphreys, W.F. (eds), Ecosystems of the World, 30: Subterranean Ecosystems: 3-14. Elsevier, Amsterdam.

Humphreys, W.F. (2008). Rising from Down Under: developments in subterranean biodiversity in Australia from a groundwater perspective. Invertebrate Systematics 22: 85-101.

Huys R. (2009). Unresolved cases of type fixation, synonymy and homonymy in harpacticoid copepod nomenclature (Crustacea: Copepoda). Zootaxa 2183: 1-99.

Huys, R. and Boxshall, G.A. (1991). Copepod Evolution. The
Ray Society, London.

Karanovic, I. (2007). Candoninae ostracods from the Pilbara region in Western Australia. Crustaceana Monographs 7: $1-432$.

Karanovic, T. (2004). Subterranean Copepoda from arid Western Australia. Crustaceana Monographs 3: 1-366.

Karanovic, T. (2006). Subterranean copepods (Crustacea, Copepoda) from the Pilbara region in Western Australia. Records of the Western Australian Museum Supplement 70: 1-239.

Karanovic, T. (2008). Marine interstitial Poecilostomatoida and Cyclopoida (Copepoda) of Australia. Crustaceana Monographs 9: 1-331.

Karanovic, T. (2010). First record of the harpacticoid genus Nitocrellopsis (Copepoda, Ameiridae) in Australia, with descriptions of three new species. International Journal of Limnology 46: 216-248.

Karanovic, T. and Cooper, S.J.B. (2011a) Molecular and morphological evidence for short range endemism in the Kinnecaris solitaria complex (Copepoda: Parastenocarididae), with description of seven new species. Zootaxa 3026: 1-64.

Karanovic, T. and Cooper, S.J.B. (2011b). Third genus of paratenocaridid copepods from Australia supported by molecular evidence (Copepoda, Harpacticoida). In Defaye, D., Suárez-Morales, E. and von Vaupel Klein, J.C. (Eds). Crustaceana Monographs, Studies on Freshwater Copepoda: a Volume in Honour of Bernard Dussart, Brill: 293-337.

Karanovic, T. and Cooper, S.J.B. (2012). Explosive radiation of the genus Schizopera on a small subterranean island in Western Australia (Copepoda: Harpacticoida): unravelling the cases of cryptic speciation, size differentiation and multiple invasions. Invertebrate Systematics 26: 115-192.

Karanovic, T., Eberhard, S.M. and Murdoch, A. (2011). A cladistic analysis and taxonomic revision of Australian Metacyclops and Goniocyclops, with description of four new species and three new genera (Copepoda, Cyclopoida). Crustaceana 84: 1-67.

Karanovic, T. and Krajicek, M. (2012). First molecular data on the Western Australian Diacyclops (Copepoda, Cyclopoida) confirm morpho-species but question size differentiation and monophyly of the alticola-group. Crustaceana $\mathbf{8 5}$ : $1549-1569$.

Klie, W. (1923). Über eine neue Brackwasserart der Harpacticoiden-Gattung Amphiascus. Archiv für Hydrobiologie 14: 335-339.

Kumar, S., Dudley, J., Nei, M. and Tamura, K. (2008). MEGA: A biologist-centric software for evolutionary analysis of DNA and protein sequences. Briefings in Bioinformatics 9: 299-306.

Lang, K. (1948). Monographie der Harpacticiden, A-B. Nordiska Bokhandeln: Lund.

Lang, K. (1965). Copepoda Harpacticoida from the Californian Pacific Coast. Kungliga Svenska Vetensk-Akademiens Handlingar, Fjarde Serien, Almquist and Wiksell, Stockholm 10: 1-560.

Lefébure, T., Douady, C. J., Gouy, M. and Gibert, J. (2006). Relationship between morphological taxonomy and molecular divergence within Crustacea: Proposal of a molecular threshold to help species delimination. Molecular Phylogenetics and Evolution 40: 435-447.

Leys, R. and Watts, C.H. (2008). Systematics and evolution of the Australian subterranean hydroporine diving beetles 
(Dytiscidae), with notes on Carabhydrus. Invertebrate Systematics 22: 217-225.

Mielke, W. (1992). Description of some benthic Copepoda from Chile and a discussion on the relationships of Paraschizopera and Schizopera (Diosaccidae). Microfauna Marina 7: 79-100.

Mielke, W. (1995). Species of the taxon Schizopera (Copepoda) from the Pacific coast of Costa Rica. Microfauna Marina 10: 89-116.

Posada, D. and Crandall, K.A. (1998). Modeltest: testing the model of DNA substitution. Bioinformatics 14: 817-818.

Rambaut, A. and Drummond, A.J. (2007). Tracer: MCMC Trace Analysis Package.

Rodríguez, F., Oliver, J. F., Marín, A. and Medina, J.R. (1990). The general stochastic model of nucleotide substitutions. Journal of Theoretical Biology 142: 485-501.

Ronquist, F. and Huelsenbeck, J.P. (2003). MRBAYES 3: Bayesian phylogenetic inference under mixed models. Bioinformatics 19: 1572-1574.

Rouch, R. and Chappuis, P.A. (1960). Sur quelques Copépodes Harpacticoides du lac Tanganika. Revue de Zoologie et de Botanique Africaines 61: 283-286.

Sakaguchi, S.O. and Ueda, H. (2010). A new species of Pseudodiaptomus (Copepoda: Calanoida) from Japan, with notes on closely related P. inopinus Burckhardt, 1913 from Kyushu Island. Zootaxa 2623: 52-68.

Sars, G.O. (1905). Pacifische Plankton-Crustaceen; Ergebnisse einer Reise nach dem Pacific Schauinsland 1896-1897, II. Brackwasser-Crustaceen von den Chatham-Inseln. Zoologische Jahrbücher, Abteilung für Systematik 21: 371-414.
Sars, G.O. (1909). Zoological results of the Third Tanganyika Expedition, Report on the Copepoda. Proceedings of the Zoological Society of London 1909: 31-77.

Stock, J.K. and von Vaupel Klein, J.C. (1996). Mounting media revisited: the suitability of Reyne's fluid for small crustaceans. Crustaceana 69: 749-798.

Storey, A.W., Halse, S.A. and Shiel, R.J. (1993). Aquatic invertebrate fauna of the Two Peoples Bay area, soutwestern Australia. Journal of the Royal Society of Western Australia 76: $25-32$.

Walter, T.C. and Boxshall, G. (2013). World Copepoda database. http://www.marinespecies.org/copepoda/aphia. $\mathrm{php}$ ? $\mathrm{p}=$ taxdetails\&id $=115135$. Accessed on 12 September 2013.

Watts, C.H.S. and Humphreys, W.F. (2006). Twenty-six new Dytiscidae (Coleoptera) of the genera Limbodessus Guignot and Nirripirti Watts and Humphreys from underground waters in Australia. Transaction of the Royal Society of South Australia 130: 123-185.

Wells J.B.J. (2007). An annotated checklist and keys to the species of Copepoda Harpacticoida. Zootaxa 1568: 1-872.

Wells, J.B.J. and Rao, G.C. (1976). The relationship of the genus Schizopera Sars within the family Diosaccidae (Copepoda: Harpacticoida). Zoological Journal of the Linnean Society 58: 79-90.

Yang, Z. (1996). Among-site rate variation and its impact on phylogenetic analyses. Trends in Ecology and Evolution 11: 367-372.

MANUSCRIPT RECEIVED 23 SEPTEMBER 2013; ACCEPTED 25 NOVEMBER 2013. 